\title{
Ergenlerde Psikolojik Sağlamlı̆̆ın Sosyal Dışlanma, Sosyal Kaygı, Cinsiyet ve Sınıf Düzeyi Açısından İncelenmesi ${ }^{1}$
}

DOI: $10.26466 /$ opus.642037

\author{
Yakup Ișık* - Eyüp Çelik ** \\ * M.A., Sakarya Üniversitesi, Eğitim Fakültesi, Hendek / Sakarya / Türkiye \\ E-Posta: pdr.yakub@gmail.com \\ ORCID: 0000-0001-5499-3544 \\ ** Doç. Dr., Sakarya Üniversitesi, Eğitim Fakültesi, Hendek / Sakarya / Türkiye \\ E-Posta: eyupcelik@sakarya.edu.tr \\ ORCID: $\underline{0000-0002-7714-9263}$
}

$\ddot{O} z$

Bu araştırmada ergenlerde psikolojik sağlamlık düzeyi sosyal dışlanma, sosyal kayğ, cinsiyet ve sinı düzeyi açısından incelenmiştir. Araştırmada veri toplama araçları olarak Çocuk ve Genç Psikolojik Sağlamlık Ölçeği (ÇGPSÖ-12), Ergenler İçin Sosyal Dışlanma Yaşantısı Ölçeği (ESDYÖ) ve Ergenler İçin Sosyal Kaygı Ölçeği (ESKÖ) kullanılmıştır. Araştırmanın çalışma grubu, 2017-2018 eğitim öğretim yılında İstanbul'un Başakşehir (1 lise), Bayrampaşa (1 lise), Gaziosmanpaşa (1 lise) ve Sultangazi (4 ortaokul, 2 lise) ilçelerinden farklı nitelikteki devlet okullarını 7, 8, 9, 10 ve 11. sinıfina devam eden gönüllü 521 öğrenciden oluşmaktadir. Bu okullarm 2'si Ortaokul, 2'si İmam Hatip Ortaokulu 2'si Anadolu Lisesi, 1'i İmam Hatip Lisesi ve 2'si Mesleki ve Teknik Anadolu Lisesi olmak üzere toplam sayısi 9'dur. Katılimclarm 258'i (\%49.5) klz, 263'ü (\%50.5) erkek öğrenciden oluşmakta, 97'si (\%18.62) 7. sinıfa, 116'sı (\%22.26) 8. sinıfa, 108'i (\%20.73) 9. sinufa, 103'ü (\%19.77) 10. simffa ve 97'si (\%18.62) 11. sinffa devam etmektedir. Verilerin analizinde korelasyon analizi, regresyon analizi, t-test ve tek yönlü varyans analizi yöntemleri kullanılmıştır. Araştırmada sosyal dışlanmanın alt boyutlarının her ikisiyle (görmezden gelinme, dışlanma) ve sosyal kaygı ile psikolojik sağlamlık arasında negatif anlamlı ilişkiler tespit edilmiş, ayrıca görmezden gelinme, dışlanma ve sosyal kaygının psikolojik sağlamlığın anlamlı yordayıcıları olduğu sonucuna ulaşılmıştır. Öte yandan cinsiyet değişkeni açısından psikolojik sağlamlık düzeyi anlaml farklllık göstermezken, sinıf düzeyi açısından bakıldığında 9. sinıfa devam eden ergenlerin psikolojik sağlamlığının 7. sinıfa devam edenlere kıyasla oldukça düşük düzeyde olduğu sonuçlarma ulaşılmıştır. Elde edilen bulgular alanyazın ışı̆̆ında tartışılmıştır.

Anahtar Kelimeler: Psikolojik sağlamlık; sosyal dışlanma; sosyal kaygl; ergenlik.

\footnotetext{
${ }^{1}$ Bu çalışma, birinci yazarın yüksek lisans tezinin bir bölümüdür
} 


\title{
Investigation of Resilience in Adolescents with Regards to Ostracism, Social Anxiety Gender and Grade Level
}

\begin{abstract}
This study examines resilience level among adolesences in terms of ostracism, social anxiety, gender and grade level. The Child and Youth Resilience Measure, The Ostracism Experience Scale For Adolescents and The Social Anxiety Scale For Adolescents were used as data collection tools. The sample of this study consists of volunteer 521 students, studying in 7 th, 8 th, 9th, 10th and 11th grades of public middle and high schools have different qualifications in districts of Isatanbul, Başakşehir (1 high school), Bayrampaşa (1 high school), Gaziosmanpaşa (1 high school) and Sultangazi (4 middle school, 2 high school) in 2017-2018 academic year. 2 of these schools are middle schools, 2 are Imam Hatip Middle Schools, 1 is Anatolian Imam Hatip High School, 2 are Anatolian High Schools and 2 are Vocational and Technical Anatolian High schools, in this way total nuber of the schools are 9. 258 $(49.5 \%)$ of participants are female and $263(50.5 \%)$ are male. $97(\% 18.62)$ of participants are in 7 th grade, $116(\% 22.26)$ are in 8 th, $108(\% 20.73)$ are in 9 th, $103(\% 19.77)$ are in 10 th and $97(\% 18.62)$ are in 11th grade. Correlation, regression, $t$-test and one way varience analysis methods were used to analyze the data. The study demonstrates that there are meaningful negative relations between resilience levels and the subscales of ostracism (being ignored, being excluded) and social anxiety levels. It is obtained that being ignored, being excluded and social anxiety are significant predictors of resilience. It is observed that the resilience level of adolescents doesn't differ by gender and compered to 7 th grade, 9th grade students' resilience level are sinificantly lower. The findings were discussed in the light of the literature.
\end{abstract}

Keywords: Resilience, ostracism, social anxiety, adolescence, 


\section{Giriş}

Ruh sağlığı alanında yapılan araştırmalar bireyleri güçlü kılan ya da kırılgan hale getiren çeşitli olguları ortaya koymaktadır. Bu bağlamda psikolojik sağlamlık da ruh sağlığının korunmasındaki önemine araştırmacıların dikkat çektiği bir kavramdır (Carr, 2013; Eryılmaz, 2013; Gable ve Haidth, 2005; Masten ve Coatsworth, 1995; Öz ve Yılmaz, 2009). Psikolojik sağlamlık; hastalıktan, depresyondan, değişimlerden ya da kötü durumlardan hızlıca iyileşme, kendini toparlayabilme (Earvolino-Ramirez, 2007); zorluk, travma, trajedi, tehdit, aile ve ilişki problemleri gibi yoğun stres kaynakları, çalışma ortamı ve finansal sorunların ortaya çıardığı stres durumlarıyla karşılaşıldığında iyi bir uyum sergileme süreci şeklinde tanımlanmaktadır (APA, 2019; Newman, 2005). Araştırmalar, psikolojik sağlamlık ile; akademik başarı (Açıkgöz 2016; Toplu, 2017), okula devam (Toplu, 2017), öğrenilmiş güçlülük (Dayıoğlu, 2008), iyimserlik ve psikolojik iyi oluş (Souri ve Hasanirad, 2011), mutluluk (Açıköz, 2016; Toprak, 2014), yaşam doyumu (Altundağ, 2013; Batan ve Ayten, 2015; Toprak, 2014; Ülker-Tümlü ve Recepoğlu 2013), kendine yönelik olumlu tutum (Chung, 2008), mizah (Mete, 2017), duygusal zeka ve umut (Aydın, 2010) arasında pozitif anlamlı ilişkiler olduğunu göstermektedir.

Ruh sağlığının korunmasında psikolojik sağlamlığın önemli bir yeri olduğu gibi, psikolojik sağlamlığın geliştirilmesinde de risk ve koruyucu faktörlerin belirlenmesinin önemli bir yere sahip olduğu belirtilmektedir (Öz ve Yılmaz, 2009). Alanyazında risk ve koruyucu unsurların kaynakları itibariyle bireysel, ailesel ve sosyal olmak üzere üç temel başlık altında ele alındığ1 görülmektedir (Garmezy, 1987; Haase, 2004; Masten ve Coasworth, 1998; Werner, 1989). Yas, göç, şiddet, ekonomik yetersizlikler, olumsuz ebeveyn tutumları gibi ailesel ve sosyal pek çok risk faktöründen söz edilebileceği gibi birey bu risk faktörlerine maruz kalmasa bile içinde bulunduğu gelişim dönemlerine özgü çeşitli risk unsurlarıyla karşılaşabilmektedir. Bu açıdan bakıldığında bireyin baş etmek durumunda olduğu biyopsikososyal değişimlerin önemli bir artış gösterdiği ergenlik döneminin başlı başına bir riskler bütünü olduğu söylenebilir.

Ergen birey bir yandan bedeninde meydana gelen biyolojik değişikliklerin etki ve sonuçlarıyla başa çımak ve uyum sağlamak durumundayken (Eskin, 2000; Onur, 1993) diğer taraftan kimlik karmaşası yaşamaktadır 
(Erikson, 2014; Dereboy, 1993). Bu süreçler devam ederken başka bir taraftan da eğitim kademesinin değişmesiyle okulu, sosyal çevresi belirgin bir değişikliğe uğramakta, alışageldiği tanıdık ve görece korunaklı ortamından çıkıp artık yeni, farklı akran ve yetişkinlerin olduğu, ayrıca daha fazla sorumluluk yüklendiği bir eğitim kademesine yani ortaokuldan liseye geçmektedir. Ergen birey için yeteri kadar zorlayıcı olan bu süreçlere bir de olumsuz ebeveyn tutumları, aile içi şiddet, ekonomik sorunlar ve sağlık problemleri gibi ailesel ve sosyal risk faktörlerinin eklenmesiyle ortaya daha da zorlu bir tablonun çıktğı söylenebilir. Bunun sonucunda okul terkleri, suça sürüklenme, zararlı alışkanlıklar, madde kötüye kullanımı ve intihar eğilimi gibi davranış problemleriyle karşılaşılabilmektedir (ASPB, 2014). Araştırmalar bütün bu davranış problemleriyle birlikte, ruh sağlığı sorunlarının da sıklıkla kendini ergenlik döneminde gösterdiği (Erol, Kılıç, Ulusoy, Keçeci ve Şimşek, 1998) ve bu bozuklukların yetişkinliğe de taşındığına dikkat çekmektedir (Çuhadaroğlu, Canat, Kılıç, Şenol, Rugancı, Öncü, ... Avc1, 2004; Offer, Kaiz, Howard ve Bennett, 1998).

Ergenlik döneminde davranış problemlerine ve ruh sağlığı sorunlarına yatkınlığın bu kadar yüksek olduğu düşünüldüğünde psikolojik sağlamlığın bu dönem açısından öneminin daha da belirginleștiği söylenebilir. Nitekim yapılan araştırmalar psikolojik sağlamlık ile okul bağlılığı (Turgut, 2015), sosyal bağlılık (Başak, 2012; Mete, 2017), sosyal destek (Dayığlu, 2008; Esen-Aktay, 2010; Magno, 2008; Terzi, 2016; Turgut, 2015), arkadaş ve öğretmen sosyal desteği (Mete, 2017; Turan, 2014) arasında pozitif ilişkilerin olduğunu göstermektedir. Benzer şekilde Bulut (2016) ergenlerde arkadaş desteği ile psikolojik sağlamlık arasında pozitif ilişki tespit ederken, Algünerhan (2017) ise 12-14 yaş ergenlerde yakın arkadaş sayısına göre psikolojik sağlamlık düzeyleri arasında anlamlı farklılıklar olduğu sonucunu elde etmiştir.

Araştırma sonuçları sosyal desteğin psikolojik sağlamlık açısından önemli bir koruyucu faktör olduğunu göstermesine karşın bazı koşullarda bireyler sosyal ilişkiler kurmakta ve dolayısıyla sosyal destek edinmekte zorluk yaşayabilmektedir. Bu koşullardan biri olarak ele alınabilecek sosyal dışlanma, bireyin grubun dişında tutulması ya da bireyle başka bireylerin ilişki kurmaması şeklinde tanımlanmaktadır (Leary, 2005). Dışlanmanın bireyler üzerindeki etkilerini inceleyen Williams (2001), "gereksinim-tehdit" modelini geliştirmiş ve bu modele göre sosyal dışlanmaya maruz kalmanın; 
ait olma, olumlu benlik değerine sahip olma, kontrol ve anlamlı varoluş gibi temel gereksinimler açısından tehdit oluşturduğunu ortaya koyarak dışlanmanın tehdit ettiği ihtiyaca göre bireyin geliştireceği tepkinin farklllık gösterebileceğini bildirmiştir. Söz gelimi Twenge, Catanese ve Baumeister (2002) dışlanmanın ait olma ihtiyacını tehdit etmesi durumunda bireyin saldırgan davranışlara yöneldiğini belirtirken, Williams (2007) bireyin bu durumda antisosyal davranışlardan ziyade, sosyal bağlarını onarmaya çalışarak kendini tekrar kabul ettirmeye yöneleceği ya da kuracağı yeni ilişkilerde olumlu ve yapıcı sosyal davranışlara yöneleceğini belirtmiştir. Bu açıdan Kandemir (2011) de dışlanmanın olumlu sosyal davranışlara mı yoksa olumsuz davranışlara mı yol açacağının, bireysel ve ortamsal değişkenlerin düzenleyici etkilerine bağlı olduğunu belirtmektedir.

Alanyazında dışlanmaya maruz kalmanın bireyde meydana getirdiği etkilerle ilgili farklı araştırmalar da yer almaktadır. Baumeister, Twenge ve Nuss (2002) yaptıkları araştırmada dışlanmanın mantıklı ve dikkatli düşünme üzerinde olumsuz bir etkisinin olduğunu tespit etmişlerdir. Twenge, Catanese ve Baumeister (2003) ise araştırmalarında, dışlanmanın zaman algısında bozulmaya yol açtı̆̆ bulgusuna ulaşmışlardır. Yapılan başka çalışmalarda dışlanma deneyimini yaşayan bireyler arasında alkol ve madde bağımlılığı, aşırı yeme, dikkatsiz otomobil kullanımı gibi davranışların daha yaygin olduğu ifade edilmiştir (Baumeister, 1997; Twenge ve diğerleri, 2002; Waldrip, 2007; Zhong ve Leonardelli, 2008). Araştırma sonuçlarına bakarak sosyal dışlanma deneyiminin bireyde algısal, duygusal ve davranışsal anlamda önemli etkiler meydana getirdiği ve başka bir açıdan da bireyin sosyal destekten mahrum kalmasıyla sonuçlandığı söylenebilir.

Sosyal dişlanma durumunda gerçek bir dişlanma deneyimine maruz kalma söz konusuyken bazı koşullarda ise birey gerçek bir dışlanmaya maruz kalmasa da başkalarının kendisini nasıl değerlendirdiği ile ilgili yüksek duyarlılığ dan uzak durabilmektedir. Bu durum ise alanyazında yer alan sosyal kayg1 kavramına karşılık gelebilir. Nitekim Öztürk (2002) sosyal kaygıyı; bireyin başkalarının yanında küçük düşecek, sıkıntı ya da utanç duyacak bir davranışta bulunmaktan korkması, bu nedenle başkalarıyla iletişim kurmaktan veya herhangi bir eylemi başkalarının önünde yapmayı gerektiren durumlardan kaçınması şeklinde ifade etmiştir. Leary ve Kowalski, (1995) sosyal kaygının, bireyin içinde bulunduğu sosyal ortamlarda başkaları tarafından 
nasıl algılandığı ve değerlendirildiğiyle aşırı ilgilenmesinden kaynakland1ğını ve sadece başkaları tarafından izlenip değerlendirilirken değil bu durum ihtimal düzeyindeyken bile yaşanabildiğini belirtmektedir. Diğer taraftan sosyal kaygısı olan bireylerin eleştirilmeye ve olumsuz değerlendirilmeye karşı yüksek duyarlılık gösterdiği, benlik saygılarının düşük ve kendilerine güvenlerinin yetersiz olduğu, bundan dolayı kendi haklarını savunmada bile güçlük yaşadıkları bildirilmektedir (Eriş ve İkiz, 2013; Işık ve Taner, 2006). Öztürk (2004) ise bu bireyler için sosyal süreçlerin bu kadar tehditkâr ve huzursuz edici oluşunun onları başka insanlarla daha yüzeysel ve uzak ilişki kurmaya ittiğini, bu sayede kendilerini çok daha iyi ve güvende hissettiklerini, çünkü ileride yaşayabilecekleri reddedilme riskini ortadan kaldırmış olduklarını belirtmektedir.

Araştırmalar sosyal kaygının ergenlerde yaygın görüldügünü, düşük ders başarısı, kilo alımı, olumsuz sosyal ilişkiler ve ebeveyn ile yakınlığın azalması davranışlarıyla ilişkili olduğunu (Mehtalia ve Vankar, 2004), öte taraftan sosyal kaygı düzeyi yüksek öğrencilerin, arkadaşları tarafından daha az kabul gördükleri, başkalarının ilgisini daha az çektikleri ve arkadaşları ile paylaşımlarının kısıtlı düzeyde olduğu bildirilmektedir (La Greca ve Lopez, 1998). İnternet kullanımı ile sosyal kaygı arasındaki ilişkileri inceleyen araştırmalarda ise sosyal kaygısı yüksek olan bireylerin problemli internet kullanımı (Zorbaz, 2013) ve internet bağımlılığı davranışları (Canoğulları, 2014) sergiledikleri görülmüştür. Xu, Schneier, Heimberg, Pirincisvalle, Liebowitz, Wang ve Blanco (2012) de araştırmalarında sosyal kaygının yaşam boyunca kadınlarda erkeklerden daha fazla görüldüğünü, kadınların sosyal kaygiyla baş etmek ve daha iyi hissetmek için ilaç tedavisine, erkeklerin ise alkol veya madde kullanımına yöneldiklerine dair bulgular elde etmişlerdir.

Risk ve koruyucu faktörlerin karşılıklı etkileşimiyle ortaya çıtığı ve dinamik bir süreç olduğu bildirilen psikolojik sağlamlıkta (Rutter, 1999), hangi unsurların risk, hangi unsurların koruyucu rol üstlendiği ve diğer taraftan hangi unsurların etkisiz olduğunun belirlenmesi önemli bir gerekliliktir (Arslan, 2015; Öz ve Yılmaz, 2009). Bu açıdan, bireylerin sosyalleşme süreçlerinde karşılaşabildiği dışlanma ve sosyal kaygı deneyimlerinin yıkıcı sonuçları (Baumeister, 1997; Canoğulları, 2014; La Greca ve Lopez, 1998; Mehtalia ve Vankar, 2004; Twenge ve diğerleri, 2002; Waldrip, 2007; Zhong ve Leonardelli, 2008; Zorbaz, 2013) ile akran ilişkilerinin ve sosyal kabulün 
önem kazandığı ergenlik döneminin (Kulaksızoğlu, 2000 ve Steinberg, 2007) kendine özgü koşulları birlikte değerlendirildiğinde, belirtilen olgular arasındaki ilişkilerin bu yaş grubu açısından betimlenmesinin önemli olduğu söylenebilir.

\section{Yöntem}

\section{Araştırmanın Modeli}

Araştırma nicel araştırma modellerinden ilişkisel tarama modeli kullanılarak gerçekleştirilmiştir. Karasar (2004)'e göre tarama modelleri, geçmişte ya da halen var olan bir durumu olduğu gibi betimlemeyi amaçlayan yöntemlerdir. Yani araştırmaya konu olan olay, kişi veya nesne kendi şartları altında, olduğu gibi tanımlanmaya çalışılır, bunları hiçbir şekilde değiştirme, etkileme çabası gösterilmez. İlişkisel tarama modeli ise tarama modelinin bir türü olup iki ya da daha çok değişken arasında birlikte değişimin varlığını ve derecesini belirlemek için kullanılan modeldir. Bu araştırmada ilişkisel tarama modeli kapsamında ergenlerin psikolojik sağlamlık düzeyleri sosyal kaygı, sosyal dışlanma, cinsiyet ve sınıf düzeyleri açısından incelenmiştir.

\section{Çalışma Grubu}

Araştırmanın çalışma grubu, 2017-2018 eğitim öğretim yılında İstanbul'un Başakşehir (1 lise), Bayrampaşa (1 lise), Gaziosmanpaşa (1 lise) ve Sultangazi (4 ortaokul, 2 lise) ilçelerinden farklı nitelikteki devlet okullarının 7, 8, 9, 10 ve 11. sınıfına devam eden gönüllü 521 öğrenciden oluşmaktadır. Bu okulların 2'si Ortaokul, 2'si İmam Hatip Ortaokulu 2'si Anadolu Lisesi, 1'i İmam Hatip Lisesi ve 2'si Mesleki ve Teknik Anadolu Lisesi olmak üzere toplam sayısı 9'dur. Katılımciların 258'i (\%49.5) kız, 263'ü (\%50.5) erkek öğrenciden oluşmakta, 97'si (\%18.62) 7. sınıfa, 116'sı (\%22.26) 8. sinıfa, 108'i (\%20.73) 9. sinıfa, 103'ü (\%19.77) 10. sinıfa ve 97'si (\%18.62) 11. sinufa devam etmektedir. 


\section{Veri Toplama Araçları}

Çocuk ve Genç Psikolojik Sağlamlık Ölçeği (ÇGPSÖ-12): Liebenberg, Ungar ve Van de Vijver (2012) tarafından geliştirilen, Liebenberg, Ungar ve LeBlanc (2013) tarafından 12 maddelik kısa form çalışması yapılan ve Arslan (2015) tarafından Türkçe'ye uyarlaması yapılmıştır. Çocuk ve Genç Psikolojik Sağlamlık Ölçeği (ÇGPSÖ-12) 12 maddeden oluşan, 5'li (1 = hiç uygun değil, 2 = çok az uygun, 3 = kısmen uygun, 4 = oldukça uygun, 5 = tamamen uygun) likert tipi ve tek boyutlu bir ölçme aracıdır. Ölçekte ters kodlanan maddeye yer verilmemiştir. Arslan (2015) tarafından Türkçe uyarlaması, ortaokul ve lisede öğrenim gören, yaşları 11 ile 16 arasında değişen bir örneklem üzerinde yapılmıştır. Açımlayıcı ve doğrulayıc faktör analizi sonuçları, ölçeğin toplam varyansın \% 51.28'ini açıklayan 12 maddelik tek faktörden meydana geldiğini göstermiştir. Güvenirlik çalışması kapsamında ölçeğe ilişkin iç tutarlılık katsayısı Cronbach alfa değeri .91 olarak hesaplanmıştır.

Ergenler İçin Sosyal Dışlanma Yaşantısı Ölçeği (SDYÖ): Gilman, CarterSowell, DeWall, Adams ve Carboni (2013) tarafindan geliştirilen, Sertelin Mercan (2016) tarafından Türkçe'ye uyarlanan Ergenler İçin Sosyal Dışlanma Yaşantısı Ölçeği (SDYÖ) toplam 11 maddeden oluşan, 5'li (1 = hiçbir zaman, 2 = nadiren, 3 = bazen, 4 = çoğunlukla, 5 = her zaman) likert tipi ve iki boyutlu (görmezden gelinme, dışlanma) bir ölçme aracıdır. Orijinal ölçekte toplam puan hesaplanmamıştır. Her iki alt boyut da tek başına kullanılabilir. Sertelin-Mercan (2016) tarafından uyarlaması 14-17 yaş aralığındaki ergenlerle yapılan ölçeğin açımlayıcı faktör analizi sonucunda toplam varyansın \% 56.2'sini açıklayan iki faktörlü bir yapıya sahip olduğu görülmüştür. Faktör analizi sonucunda faktör yüklerinin .83 ile .59 arasında sıralandığı görülmüştür. Ölçeğin iç tutarlılık Cronbach alfa katsayıları görmezden gelinme alt boyutu için .82, dışlanma alt boyutu için .83 olarak hesaplanmıştır. Ölçeğin test tekrar test güvenirlilik katsayıları görmezden gelinme alt boyutu için .65, dışlanma alt boyutu için .63 olarak hesaplanmıştır.

Ergenler İçin Sosyal Kaygı Ölçeği (ESKÖ): La Greca, Dandes, Wick, Shaw ve Stone (1988) tarafından geliştirilen, La Greca ve Stone (1993) tarafından revize edilen ve La Greca ve Lopez (1998) tarafindan ergenlere uyarlaması 
yapılan ölçeğin Türkçe uyarlaması ise Aydın ve Tekinsav Sütçü (2007) tarafından yapılmıştır. Ölçeğin orijinalinde toplam madde sayısı 22 'dir. Türkçe'ye uyarlanmasında ise toplam ölçek madde sayısı 18 olup, geriye kalan 4 madde ise "kitap okumayı severim", "spor yapmaktan hoşlanırım" gibi sosyal kaygı dışında kalan farklı konulardan seçilmiş dolgu maddeleri olduğundan bu maddelere Türkçe uyarlamada yer verilmemiştir. 5'li $(1=$ hiçbir zaman, 2 = nadiren, 3 = bazen, 4 = genellikle, 5 = her zaman) likert tipi ve üç boyutlu (olumsuz değerlendirilme korkusu, yeni sosyal durumlarda korku ve huzursuzluk, genel sosyal durumlarda korku ve huzursuzluk) bir ölçme aracıdır. Ölçekten hem toplam hem de alt boyutlara ilişkin puan elde edilebilmektedir. Uyarlaması Aydın ve Tekinsav Sütçü (2007) 12-15 yaş aralığındaki ilköğretim ikinci kademe (ortaokul) öğrencilerinde yapılan ölçeğinin 18 maddesine varimaks eksen döndürme yöntemine göre temel bileşenler faktör analizi uygulanmıştır. Yapısal faktör analizi sonucunda toplam varyansın \%48'ini açıklayan 3 faktör bulunmuştur. Faktör yüklerinin .78 ile .40 arasında sıralandığı görülmüştür. Güvenirlik düzeyini belirlemek amaciyla ölçeğin tümü ve alt boyutları için Cronbach Alfa iç tutarlılık katsayıları hesaplamıştır. Güvenirlik katsayıları ölçeğin tümü için 0,88 , olumsuz değerlendirme korkusu için 0,83 , genel sosyal durumlarda korku ve huzursuzluk için 0,68 ve yeni sosyal durumlarda korku ve huzursuzluk için 0,71 olarak hesaplanmıştır.

\section{Veri Analizi}

Araştırma verileri korelasyon analizi, regresyon analizi, t-testi ve tek yönlü varyans analizi kullanılarak analiz edilmiştir. Veri seti regresyon analizine alınmadan önce regresyon analizi sayıltıları açısından incelenmiştir. Verilerin regresyon analizi için uygun olup olmadığı Çokluk, Şekercioğlu ve Büyüköztürk (2012)'nin de belirttiği gibi veri setindeki çok değişkenli uç değerlerin Mahalanobis uzaklık değerleri hesaplanarak belirlenmeye çalışılmıştır. Veri setindeki çok değişkenli uç değerlerin $\mathrm{p}<.01$ anlamllık düzeyine göre değerlendirilmesiyle veri setinden 28 veri silinerek "normallik" ve "doğrusallık" sağlanmaya çalışılmıştır. Regresyon analizi öncesinde verilerin basıklık, çarpıklık değerleri ve normal dağılım grafiği incelenerek veri setinin normal dağılıma sahip olup olmadığı belirlenmeye çalışılmıştır. Ayrıca bağımsız değişkenler arasında çoklu bağlantı problemi olup olmadığı 
da VIF (Varyans Artış Faktörleri Yöntemi) ile incelenerek bu değerlerin 10'dan küçük olduğu, Tabachnick ve Fidell (2007)'nin de belirttiği şartı sağladığı, yani bağımsız değişkenler arasında çoklu bağlantı probleminin olmadığı anlaşılmıştır. Regresyon analizi sayıltılarına ilişkin sonuçlar Tablo 1 ve Şekil 1'de sunulmuştur. Regresyon analizi için gerekli şartları sağlayan veri setinin $(\mathrm{N}=521)$ yapılacak analizlere uygun olduğuna karar verilmiştir. Araştırma problemlerinin her birine ilişkin bulgular sırasıyla ele alınacaktır.

Tablo 1. Regresyon Analizi Sayıltılarnna İlişkin Sonuçlar

\begin{tabular}{lllll}
\hline Değişkenler & Çarpıklık & Basılılı & VIF & CI \\
\hline Psikolojik Sağlamlık & -.709 & .226 & & 1.000 \\
Görmezden Gelinme & 1.536 & 1.889 & 1.401 & 7.020 \\
Dişlanma & .271 & -.323 & 1.091 & 8.647 \\
Sosyal Kaygi & .519 & -.160 & 1.352 & 10.946 \\
\hline
\end{tabular}

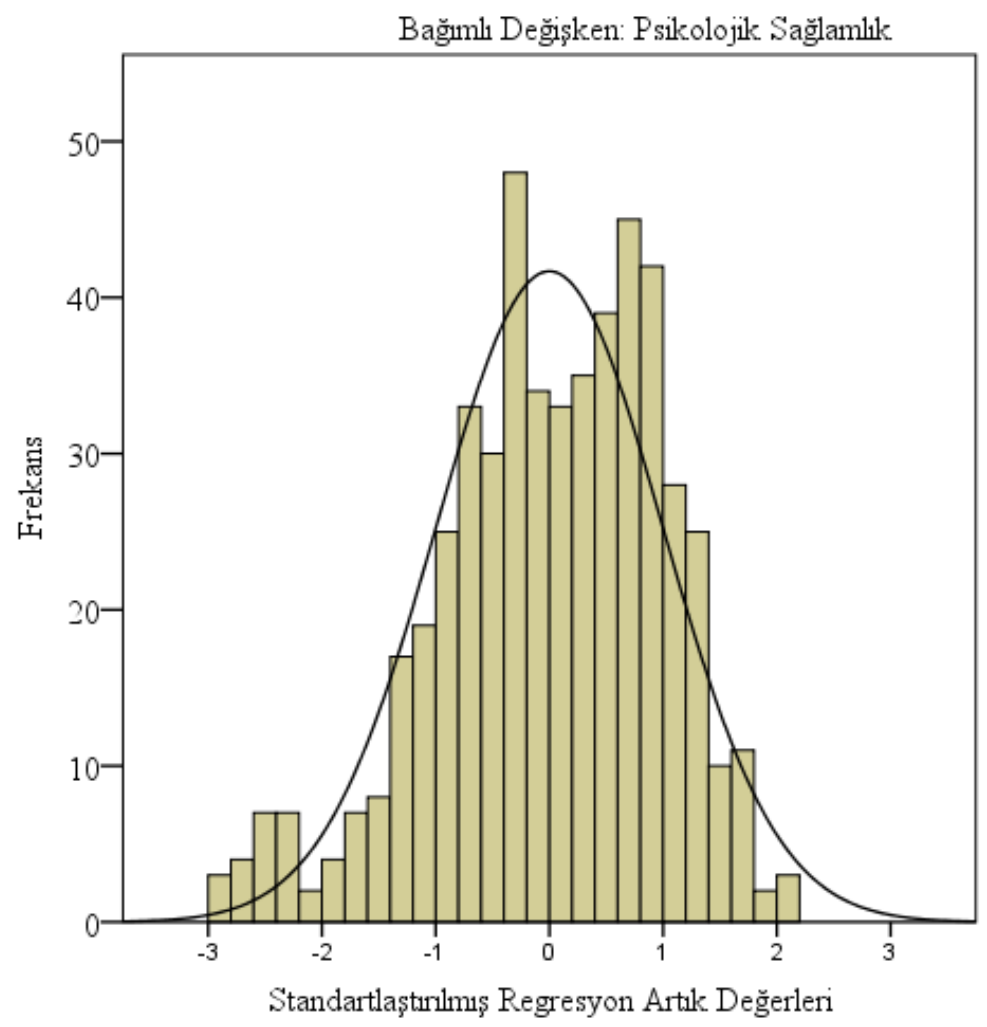

Şekil 1. Standardize Edilmiş Bağıml Değişken Psikolojik Sağlamlık Normal Dağılım Grafiği. 
Tablo 1 ve Şekil 1 İncelendiğinde araştırmaya ilişkin verilerin çarpıklık değerlerinin -.71 / 1.54 arasında, basıklık değerlerinin -.32 / 1.89 arasında olduğu sonucuna ulaşılmıştır. Çarpıklık ve basıklık değerlerinin \pm 2 aralığında yer almasının normallikten aşırı sapmalar olmaması şeklinde yorumlandığı bildirilmektedir (George ve Mallery, 2010). Buna bakarak araştırma verilerimizin bu şartı sağladığı görülmektedir.

\section{Bulgular}

\section{Ergenlerin Psikolojik Sağlamlık Düzeylerine İlişkin Bulgular}

Tablo 2. Ergenlerin Çocuk Ve Ergen Psikolojik Sağlamlık Ölçeğinden Aldığı Puanların Dağılımı

\begin{tabular}{|c|c|c|c|c|c|c|c|c|}
\hline \multirow{2}{*}{$\begin{array}{l}\text { Ergenlerin } \\
\text { Psikolojik Sağlamlık }\end{array}$} & \multirow{2}{*}{$\mathrm{N}$} & \multirow{2}{*}{$\begin{array}{l}\text { En Düşü̈k } \\
\text { Puan }\end{array}$} & \multirow{2}{*}{$\begin{array}{l}\text { En Yüksek } \\
\text { Puan }\end{array}$} & & \multirow{2}{*}{$S$} & \multicolumn{3}{|c|}{ Yüzdelikler (\%) } \\
\hline & & & & & & $\% 25$ & $\% 50$ & $\% 75$ \\
\hline Düzeyi & 521 & 30 & 60 & 49.53 & 6.32 & 46 & 50 & 54 \\
\hline
\end{tabular}

Tablo 2'de görüldüğü gibi araştırmaya katılan ergenlerin Çocuk ve Ergen Psikolojik Sağlamlık Ölçeği'nden aldıkları puanların dağılımı incelendiğinde alınan en düşük puanın 30, en yüksek puanın ise 60 olduğu gözlenmiştir. Aritmetik ortalama 49.53, standart sapma ise 6.32 olarak hesaplanmıştır. Puanların dağılımı yüzdelikler açısından incelendiğinde ise en yüksek puanları alan \%25'lik grubun puanlarının, 54 ile 60 arasında, en düşük puanları alan $\% 25^{\prime}$ lik grubun puanlarının ise 30 ile 46 arasında değiştiği gözlenmektedir. Çocuk ve Ergen Psikolojik Sağlamlık Ölçeği'nden alınacak minimum puanın 12, maksimum puanın 60 olduğu dikkate alınırsa araştırmaya katılan ergenlerin psikolojik sağlamlık düzeylerinin çoğunlukla yüksek olduğu söylenebilir.

\section{Korelasyon Analizi}

Ergenlerde psikolojik sağlamlık düzeyleri ile sosyal dışlanma ve sosyal kayg1 düzeyleri arasındaki ilişkileri belirlemek amacıyla korelasyon analizi yapılmış ve elde edilen bulgular Tablo 3 'te sunulmuştur. İki değer arasındaki ilişkide, korelasyon katsayısının mutlak değer olarak .70 - 1.00 arasında olması yüksek düzeyde; .30-.70 arasında olması orta düzeyde; $.00-.30$ arasında olması ise düşük düzeyde bir ilişki olduğunun göstergesi olarak 
kabul edilmektedir (Büyüköztürk, 2014). Araştırmada elde edilen veriler bu bağlamda yorumlanmıştır.

Tablo 3. Ergenlerin Psikolojik Sağlamlık Düzeyi ile Sosyal Dışlanma ve Sosyal Kaygı Arasındaki İlişkilere Yönelik Korelasyon Analizi Sonucu

\begin{tabular}{lllll}
\hline Değişkenler & 1 & 2 & 3 & 4 \\
\hline Psikolojik Sağlamlık & 1 & & & \\
Görmezden Gelinme & $-.361^{* *}$ & 1 & & \\
Dişlanma & $-.204^{* *}$ & $.277^{* *}$ & 1 & \\
Sosyal Kaygi & $-.278^{* *}$ & $.505^{* *}$ & $.208^{* *}$ & 1 \\
\hline$\overline{\bar{x}}$ & 49.53 & 6.91 & 17.17 & 38.82 \\
SS & 6.32 & 2.50 & 4.84 & 11.84 \\
\hline
\end{tabular}

${ }^{*} p<.01, * p<.05$

Tablo 3 incelendiğinde, ergenlerde psikolojik sağlamlık düzeyi ile sosyal dışlanmanın alt boyutları (görmezden gelinme, dışlanma) ve sosyal kaygı arasında anlamlı ilişkiler olduğu görülmektedir. Bu doğrultuda psikolojik sağlamlık düzeyi ile, görmezden gelinme $(r=-.36)$ arasında negatif orta düzeyde; psikolojik sağlamlık düzeyi ile dışlanma $(\mathrm{r}=-.20)$ ve sosyal kaygı $(\mathrm{r}=$ -28) arasında ise negatif düşük düzeyde ve istatistiksel açıdan anlamlı ilişkilerin bulunduğu görülmüştür. Korelasyon analizi sonuçları da dikkate alınarak araştırmada sosyal dışlanma ve sosyal kayginın psikolojik sağlamlığ yordayıp yordamadığını belirlemek için regresyon analizi yapılmıştır (Büyüköztürk, 2014). Yapılan analize ve elde edilen bulgulara ilişkin detaylar bir sonraki başlık altında sunulmuştur.

\section{Regresyon Analizi}

Ergenlerde sosyal dışlanma ve sosyal kaygının psikolojik sağlamlığı istatistiksel açıdan anlamlı düzeyde yordayıp yordamadığını belirlemek amacıyla yapılan regresyon analizi sonuçları Tablo 4'te verilmiştir. 
Tablo 4. Ergenlerde Psikolojik Sağlamlık Değişkenini Sosyal Dışlanma Ve Sosyal Kayginın Yordama Düzeyine İlişkin Regresyon Analizi Sonuçlan

\begin{tabular}{|c|c|c|c|c|c|c|c|c|}
\hline \multirow[b]{2}{*}{$\begin{array}{l}\text { Bağımlı } \\
\text { değiş̧ken }\end{array}$} & \multirow[b]{2}{*}{$\begin{array}{l}\text { Yordayıcı } \\
\text { Değiken }\end{array}$} & \multirow[b]{2}{*}{$B$} & \multirow[b]{2}{*}{ SH } & \multirow[b]{2}{*}{$\beta$} & \multirow[b]{2}{*}{$t$} & \multirow[b]{2}{*}{$p$} & \multicolumn{2}{|c|}{ Korelasyon } \\
\hline & & & & & & & Kismi & $\begin{array}{l}\text { Yarı } \\
\text { Kismi }\end{array}$ \\
\hline \multirow{4}{*}{$\begin{array}{l}\text { Psikolojik } \\
\text { Saglamlık }\end{array}$} & Sabit & 59.075 & 1.168 & & 50.564 & .000 & & \\
\hline & $\begin{array}{l}\text { Görmezden } \\
\text { Gelinme }\end{array}$ & -.687 & .121 & -.272 & -5.674 & .000 & -.242 & -.230 \\
\hline & Dişlanma & -.136 & .055 & -.104 & -2.458 & .014 & -.107 & -.100 \\
\hline & Sosyal Kaygi & -.064 & .025 & -.119 & -2.529 & .012 & -.111 & -.102 \\
\hline $\begin{array}{l}F_{(3,517)}=30 . \\
R=.390 ; R\end{array}$ & $\begin{array}{l}993 . p<.01 \\
{ }^{2}=.152 ; \text { Düze }\end{array}$ & $R^{2}=.14$ & & & & & & \\
\hline
\end{tabular}

Tablo 4 incelendiğinde, görmezden gelinme $(\beta=-.27, \mathrm{p}<.001)$, dişlanma $(\beta=-.10, \mathrm{p}<.05)$, sosyal kaygı $(\beta=-.12, \mathrm{p}<.05)$ değişkenlerinin psikolojik sağlamlık değişkenini istatistiksel açıdan anlamlı düzeyde yordadığı gözlenmektedir. Elde edilen bu bulgu doğrultusunda görmezden gelinme, dışlanma ve sosyal kaygı değişkenlerinin yer aldığı bu regresyon modelinde psikolojik sağlamlık değişkeninin \% 15'ini açıkladığı sonucuna ulaşılmıştır. Tablo $4^{\prime}$ te yer alan yordayıcı değişkenlerden psikolojik sağlamlık değişkenini yordayan değişkenlere ait yarı kısmi korelasyon değerleri incelendiğinde, araştırmada sinanan regresyon modelinde psikolojik sağlamlığın \%5.29'unu görmezden gelinme, \%1'ini dışlanma ve \%1.04'ünü sosyal kaygının açıkladığı görülmektedir. Sonuç olarak bu regresyon modelinde psikolojik sağlamlığın \%7.87'sinin görmezden gelinme, dışlanma ve sosyal kaygı değişkenlerinin çakışması sonucu açıklandığı bulgusuna ulaşılmaktadir.

\section{T-Testi}

Ergenlerde psikolojik sağlamlık düzeyinin cinsiyet açısından anlamlı biçimde farklılaşıp farklılaşmadığı bağımsız örneklem $t$ testi ile incelenmiş ve elde edilen bulgu Tablo 5 'te sunulmuştur.

Tablo 5. Psikolojik Sağlamlı̆̆ın Cinsiyete Göre İncelenmesine İlişkin T Testi Sonucu

\begin{tabular}{|c|c|c|c|c|c|c|c|c|c|}
\hline & \multicolumn{4}{|c|}{ LeveneTesti } & \multicolumn{3}{|c|}{ T-Testi } & \multirow{2}{*}{\multicolumn{2}{|c|}{ 95\% Güven Aralı̆g }} \\
\hline & \multirow{2}{*}{$F$} & \multirow[b]{2}{*}{$p$} & \multirow{2}{*}{$t$} & \multirow{2}{*}{$S S$} & \multirow[b]{2}{*}{$p$} & \multirow{2}{*}{$\begin{array}{l}\text { Ortalama } \\
\text { Fark }\end{array}$} & \multirow{2}{*}{ SH } & & \\
\hline & & & & & & & & Düşük & Yüksek \\
\hline Psikolojik Sağlamlık & .319 & .572 & -1.029 & 519 & .304 & -.56958 & .55379 & -1.65752 & .351836 \\
\hline
\end{tabular}


Tablo 5 'te sunulan $\mathrm{t}$ testi sonucunda, ergenlerde psikolojik sağlamlı düzeyinin cinsiyete göre anlamlı düzeyde farklılaşmadığ $1(p>05)$ görülmüştür. (Erkek $\bar{x}=49.24, S S=6,26 ; \mathrm{K} 1 z \bar{x}=49.81, S S=6,37$ ).

\section{Tek Yönlü Varyans Analizi}

Araştırmanın örneklemini oluşturan ergenlein psikolojik sağlamlık düzeyinin sınıf düzeyleri açısından istatistiksel olarak anlamlı düzeyde farklılaşıp farklılaşmadığını belirlemek amacıyla, varyansların homojenliği Levene testi ile incelenerek $\left(\mathrm{F}_{(4,516)}=.20, \mathrm{p}>.05\right)$ tek yönlü varyans analizi yapılmıştır. Araştırmaya katılan ergenlerin psikolojik sağlamlık düzeyine ilişkin ortalama ve standart sapma değerleri Tablo 6 'da, tek yönlü varyans analizi sonucunda elde edilen bulgular ise Tablo 7 ve Şekil 2' de sunulmuştur.

Tablo 6. Ergenlerin Sınff Düzeyine Göre Psikolojik Sağlamlık Puanlarna İlişkin Betimsel İstatistik Sonuçlarn

\begin{tabular}{llrlll}
\hline Psikolojik Sağlamlık & $N$ & $\bar{x}$ & SS & En Düşük & En Yüksek \\
\hline 7. Sinıf & 97 & 51.6186 & 5.89039 & 31.00 & 60.00 \\
8. Sinıf & 116 & 49.9397 & 6.59419 & 30.00 & 59.00 \\
9. Sinıf & 108 & 47.6944 & 6.44235 & 30.00 & 60.00 \\
10.Sinuf & 103 & 48.9223 & 6.03209 & 34.00 & 60.00 \\
11.sinuf & 97 & 49.6289 & 5.98839 & 34.00 & 60.00 \\
Total & 521 & 49.5278 & 6.32027 & 30.00 & 60.00 \\
\hline
\end{tabular}

Tablo 6'da yer alan aritmetik ortalamalar incelendiğinde 7. sınıfa devam eden ergenlerin $(\bar{x}=51.62), 8$. sinifa devam eden ergenlerin $(\bar{x}=49.94)$, 9. sinifa devam eden ergenlerin $(\bar{x}=47.69)$, 10. sinifa devam eden ergenlerin $(\bar{x}=48.92)$ ve 11.sınıfa devam eden ergenlerin $(\bar{x}=49.63)$, olduğu görülmektedir. Sınıf düzeyi açısından karşılaştırıldığında 7.sınıfa devam eden ergenlerin psikolojik sağlamlık düzeyinin en yüksek olduğu, 9.sınıfa devam eden ergenlerin psikolojik sağlamlık düzeylerinin en düşük olduğu sonucuna ulaşılmıştır.

Tablo 7. Ergenlerin Sınıf Düzeyine Göre Psikolojik Sağlamlık Puanlarııın Farklılaşıp Farklılaşmadığına İlişkin Bulgular

\begin{tabular}{|c|c|c|c|c|c|c|c|}
\hline Levene testi & $p$ & Varyans Kayn & 1 Kareler Toplamı & $\mathrm{sd}$ & Kareler Ort. & $F$ & $p$ \\
\hline \multirow{3}{*}{.204} & \multirow{3}{*}{.936} & Gruplar arası & 845.448 & 4 & 211.362 & & \multirow{3}{*}{.000} \\
\hline & & Grup içi & 19926.399 & 516 & 38.617 & 5.473 & \\
\hline & & Toplam & 20771.846 & 520 & & & \\
\hline
\end{tabular}




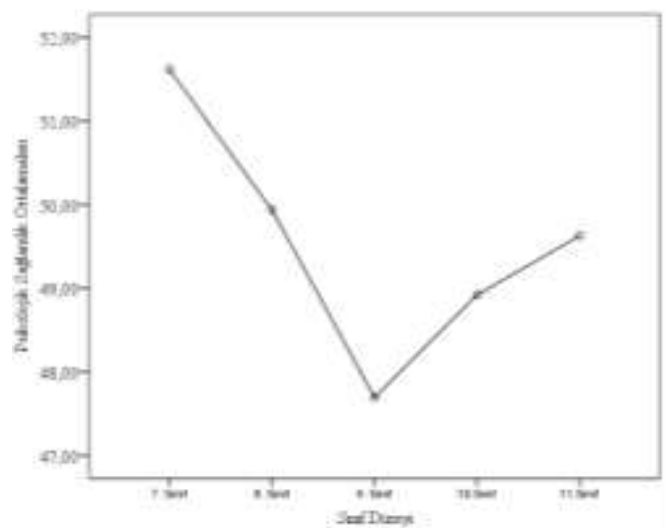

Şekil 2. Ergenlerde Sınıf Düzeyine Göre Psikolojik Sağlamlık Düzeyleri.

Tablo 7 ve Şekil 2 incelendiğinde, ergenlerde psikolojik sağlamlık düzeyinin sınıf düzeyine göre anlamlı düzeyde farklılaştı̆̆ görülmektedir $\left(F_{(4,516)}=\right.$ $5.473, p<.001)$. Tek yönlü varyans analizi sonucunda bulunan bu farklılığın hangi gruplar arasında olduğu Scheffe testi ile incelenmiş ve ulaşılan sonuçlar Tablo 8'de sunulmuştur.

Tablo 8. Ergenlerin Sınıf Düzeyine Göre Psikolojik Sağlamlı Puanlarna İlişkin Scheffe Testi Sonuçlarn

\begin{tabular}{|c|c|c|c|c|c|c|}
\hline \multirow{2}{*}{ (I) Sınıf Düzeyi } & \multirow{2}{*}{ (J) Sınıf Düzey } & \multirow{2}{*}{ Ortalama Fark (I-J) } & \multirow{2}{*}{ Standart Hata } & \multirow{2}{*}{$\mathrm{p}$} & \multicolumn{2}{|c|}{ 95\% Güven Aralığ1 } \\
\hline & & & & & Alt Sinir & Üst Sinur \\
\hline \multirow[t]{4}{*}{ 7. Sinif } & 8. sinif & 1.67890 & .85500 & .427 & -.9642 & 4.3221 \\
\hline & 9. Sinif & $3.92411^{*}$ & .86930 & .000 & 1.2368 & 6.6115 \\
\hline & 10.Sinif & 2.69623 & .87923 & .053 & -.0218 & 5.4143 \\
\hline & 11.sinif & 1.98969 & .89232 & .292 & -.7688 & 4.7482 \\
\hline \multirow[t]{4}{*}{8. sinif } & 7. Sinif & -1.67890 & .85500 & .427 & -4.3221 & .9642 \\
\hline & 9. Sinif & 2.24521 & .83095 & .123 & -.3236 & 4.8140 \\
\hline & 10.Sinif & 1.01733 & .84133 & .833 & -1.5836 & 3.6182 \\
\hline & 11.sinuf & .31079 & .85500 & .998 & -2.3324 & 2.9539 \\
\hline \multirow[t]{4}{*}{ 9. Sinuf } & 7. Sinuf & $-3.92411^{*}$ & .86930 & .000 & -6.6115 & -1.2368 \\
\hline & 8. sinif & -2.24521 & .83095 & .123 & -4.8140 & .3236 \\
\hline & 10.Sinif & -1.22789 & .85586 & .725 & -3.8737 & 1.4179 \\
\hline & 11.sınif & -1.93442 & .86930 & .294 & -4.6218 & .7529 \\
\hline \multirow[t]{4}{*}{ 10.Sinif } & 7. Sinif & -2.69623 & .87923 & .053 & -5.4143 & .0218 \\
\hline & 8. sinif & -1.01733 & .84133 & .833 & -3.6182 & 1.5836 \\
\hline & 9. Sinif & 1.22789 & .85586 & .725 & -1.4179 & 3.8737 \\
\hline & 11.sinif & -.70654 & .87923 & .958 & -3.4246 & 2.0115 \\
\hline \multirow[t]{4}{*}{ 11.sinif } & 7. Sinif & -1.98969 & .89232 & .292 & -4.7482 & .7688 \\
\hline & 8. sinif & -.31079 & .85500 & .998 & -2.9539 & 2.3324 \\
\hline & 9. Sinif & 1.93442 & .86930 & .294 & -.7529 & 4.6218 \\
\hline & 10.Sınif & .70654 & .87923 & .958 & -2.0115 & 3.4246 \\
\hline
\end{tabular}

${ }^{*} p<0.05$ 
Tablo 8 incelendiğinde, ergenlerde psikolojik sağlamlığın sınıf düzeyine göre istatistiksel açıdan anlamlı düzeyde farklılaştığı görülmektedir. Tablo 6 ve Şekil 2 incelendiğinde psikolojik sağlamlık düzeyinin 7. sinıftan 9. sinıfa doğru düşüş gösterip 9. Sınıftan 11. sınıfa doğru tekrar yükseldiği görülmektedir. Ancak Tablo 8'e göre sadece 7. sinıfa devam eden ergenler ile 9. sınıfa devam eden ergenlerin psikolojik sağlamlık düzeyleri arasındaki farkın istatistiksel açıdan anlamlı olduğu $(p<.001)$ diğer gruplar arasındaki olası karşılaştırmalarda istatistiksel açıdan anlamlı düzeyde farklılaşmanın olmadığı görülmüştür $(p>.05)$.

\section{Tartışma ve Sonuç}

Araştırmaya katılan ergenlerin psikolojik sağlamlık düzeylerinin çoğunlukla yüksek olduğu sonucu elde edilmiştir. Alanyazın incelendiğinde psikolojik sağlamlık ile okul bağlılığı (Turgut, 2015), arkadaş ve öğretmen sosyal desteği (Mete, 2017; Turan, 2014) yakın arkadaş sayısı (Algünerhan, 2017) arasında pozitif anlamlı ilişkilerin olduğu görülmektedir. Bu bulgulara bakılarak araştırma sonucunun alanyazın ile tutarlılık gösterdiği söylenebilir. Araştırmaya katılan öğrencilerin yaşam koşulları değerlendirildiğinde örgün eğitim içerisinde yer almaları sayesinde öğretmen, okul ve arkadaş sosyal desteğini alabilecek imkana sahip olmaları gibi koruyucu etkenlerin, ergenlerin psikolojik sağlamlık düzeylerinde de olumlu bir etki sağladığı söylenebilir. Öte yandan araştırmaya katılan ergenlerin yaşadıkları bölgeler farklılıklar içermekle birlikte genel olarak güvenlik, barınma, ulaşım ve sağlık hizmetlerinden yararlanabiliyor olmaları gibi olumlu çevresel ve sosyal unsurların da psikolojik sağlamlık düzeylerine olumlu bir yansıması olduğu sonucu çıkarılabilir.

Araştırmada sosyal dışlanmanın alt boyutlarından (görmezden gelinme, dışlanma) biri olan görmezden gelinme ile psikolojik sağlamlık arasında negatif yönde anlamlı ilişki bulunmuştur. Alanyazında görmezden gelinme durumunun "psikolojik dişlanma" kavramı ile ifade edildiği (Williams, 2007) fakat psikolojik sağlamlık ile görmezden gelinme ya da psikolojik dışlanma arasındaki ilişkiyi doğrudan inceleyen bir araştırmanın yer almadığı da görülmektedir. Yapılan bazı araştırmalarda psikolojik dışlanmanın bireyin anlamlı varoluş ihtiyacı (Williams ve Zadro, 2005) ve benlik değeri (Kandemir, 2011) açısından tehdit oluşturduğu bulgularının elde edildiği 
görülmektedir. Benlik değeri ve anlamlı varoluş ile ilgili olduğu düşünülebilecek kavramlardan; benlik saygisı (Kidd ve Shahar 2008; Sarıkaya, 2015), özgüven (Benetti ve Kambouropoulos, 2006), öz-yeterlilik (Magno, 2008; Toplu, 2017) ve kendine yönelik olumlu tutum (Chung, 2008) ile psikolojik sağlamlık arasında pozitif anlamlı ilişkiler bulunduğu görülmektedir. Öte yandan alanyazında yer alan diğer bulgulara göre ise psikolojik dişlanma bireyin kontrol ihtiyacın tehdit etmektedir (Kandemir, 2011; Williams ve Zadro, 2005). Alanyazında kontrol ihtiyacı ile ilgili olduğu düşünülebilecek kavramlardan; dışsal denetim odağı (Karaırmak ve Siviş-Çetinkaya, 2016), çaresiz ve boyun eğici başa çıkma yaklaşımları (Alkan, 2014), kaçıngan, erteleyici ve panik karar verme stratejileri (Yıldız, 2015) ile psikolojik sağlamlık düzeyleri arasında ise negatif anlamlı ilişkiler tespit edildiği görülmektedir. Bu sonuçlar birlikte değerlendirildiğinde alanyazındaki bulgularla araştırmadan elde edilen bulguların tutarlılık gösterdiğini savunmak mümkündür. Bu çerçevede anlamlı varoluş ihtiyac, benlik değeri ve kontrol ihtiyac1nın psikolojik sağlamlık açısından da temel bir işlev gördüğü, görmezden gelinme (psikolojik dışlanma) nedeniyle bu ihtiyaçların tehdide uğramasının, psikolojik sağlamlığı da tehdide uğrattığı savunulabilir.

Araştırmada sosyal dışlanmanın alt boyutlarından (görmezden gelinme, dışlanma) bir diğeri olan dışlanma ile psikolojik sağlamlık arasında negatif yönde anlamlı ilişki bulunmuştur. Leary (2005) dışlanmanın, bireyin grubun dışında tutulması ya da bireyle başka bireylerin ilişki kurmaması durumuna karşılık gelerek ait olma ihtiyacı ve benlik değeri için tehdit oluşturduğunu bildirmektedir. Ayrıca dışlanmanın bir diğer sonucunun da bireyin sosyal destekten mahrum kalması olduğu söylenebilir. Alanyazında psikolojik sağlamlık ile dışlanma arasındaki ilişkiyi doğrudan inceleyen bir araştırmanın yer almadığı da görülmektedir. Ait olma ihtiyacı ve sosyal destek ile ilgili olduğu düşünülebilecek kavramlarla ilgili araştırmalara bakıldığında; okul bağl1lığı (Turgut, 2015), sosyal bağllılık (Başak, 2012; Mete, 2017); sosyal destek (Dayığlu, 2008; Esen-Aktay, 2010; Magno, 2008; Terzi, 2008; Turgut, 2015) ve arkadaş ile öğretmen sosyal desteği (Bulut, 2016; Mete, 2017; Turan, 2014) değişkenlerinin psikolojik sağlamlık ile pozitif ilişkili olduğu görülmektedir. Diğer taraftan yalnızlık ile psikolojik sağlamlık arasında da negatif güçlü ve anlamlı ilişki tespit edildiği görülmektedir (Altundağ, 2013; Güloğlu ve Karairmak, 2010). Bu sonuçlar birlikte değerlendirildiğinde alanyazındaki bulgularla araştırmadan elde edilen bulguların 
tutarlılık gösterdiğini savunmak mümkündür. Bu çerçevede, ait olma ihtiyacı, benlik değeri ve sosyal desteğin bireyin psikolojik sağlamlığı için de temel bir işlev gördüğü, dolayısıyla dışlanma nedeniyle bu ihtiyaçların tehdide uğramasının, psikolojik sağlamlığın da tehdide uğraması anlamına geldiği sonucu çıkarılabilir.

Araştırmada ergenlerde sosyal kaygı ile psikolojik sağlamlık arasında düşük düzeyde ve negatif ilişki bulunmuştur. Alanyazında ergen yaş grubunda psikolojik sağlamlık ile sosyal kaygıyı inceleyn bir araştırmanın yer almadığı görülmektedir. Konusu itibariyle bu araştırmaya en yakın çalışma olan Atarbay (2017)'nin üniversite öğrencileri üzerinde yaptığı araştırmada sosyal kaygı ile psikolojik sağlamlık arasında anlamlı bir ilişki tespit edilmediği görülmektedir. Diğer taraftan alanyazında psikolojik sağlamlık ile pozitif ilişkisi bulunan benlik saygısıyla (Kidd ve Shahar, 2008; Sarıkaya, 2015) sosyal kaygı arasındaki ilişkiyi inceleyen araştırmalar da görülmektedir. Eriş ve İkiz (2013) ergenler üzerinde yaptıkları araştırmada benlik sayg1Sı ile sosyal kaygı arasında negatif bir ilişki tespit etmişlerdir yani benlik saygısı artarken sosyal kaygı düzeyinin düştüğü sonucuna ulaşılmıştır. Başka bir çalışmada Çankaya (2007) benzer şekilde benlik saygısı yüksek olan lise öğrencilerinin düşük sosyal kaygı düzeyine sahip olduklarını tespit etmiştir. Bu bulgulara bakarak araştırma sonuçlarının alanyazın ile tutarlılık gösterdiği savunulabilir. Sosyal kaygı ile psikolojik sağlamlığın yetişkin ve ergen yaş gruplarında farklı ilişkiler göstermesinin olası nedenlerinden biri ergenlik döneminin kendine özgü koşulları olabilir. Ergen bireyin biyopsikososyal anlamda (fiziksel gelişim, beden imajı ve kimlik gelişimi gibi) çok yönlü değişimlere uyum sağlamak durumunda oluşu nedeniyle yetişkin bireylere oranla daha fazla stres faktörü ile aynı anda başa çıkmaya çalıştığı söylenebilir. Bu çerçevede ergen bireyin mevcut koruyucu kaynaklarının söz konusu çok yönlü stres ve kaygıyı tolere etmede yetersiz kaldığı, bu nedenle de sosyal kaygının yetişkinlere göre ergenlerin psikolojik sağlaml-ğında daha belirleyici bir rol oynadığı savunulabilir. Bu çerçevede, psikolojik sağlamlık ile pozitif ilişkisi bulunan benlik saygısının (Kidd ve Shahar, 2008; Sarıkaya, 2015), soyal kaygı nedeniyle düşüş göstermesinin (Eriş ve İkiz, 2013; Çankaya, 2007), psikolojik sağlamlık düzeyinde de düşüşü beraberinde getirdiği savunulabilir.

Araştırmada sosyal dışlanmanın her iki alt boyutu (görmezden gelinme, dışlanma) ile sosyal kaygı değişkenlerinden her birinin psikolojik sağlamlı- 
ğın anlamlı birer yordayıcıları olduğu ve sosyal dışlanma ile sosyal kaygiyı aynı anda yaşayan ergenin psikolojik sağlamlık düzeyinin daha büyük oranda olumsuz etkilendiği bulgusu elde edilmiştir. Alanyazında psikolojik sağlamlık açısından; özgüven ve yüksek özsaygı gibi kişinin sahip olduğu kişisel kaynaklar ile kendisine dair olumlu tutumları, bireysel düzeyde koruyucu nitelik taşırken, bu kaynakların yetersizliği bireysel risk unsurları kapsamında ele alınmaktadır (Eminağaoğlu, 2006; Masten, 1994; Romano ve Hage, 2000). Benzer şekilde sosyal destek psikolojik sağlamlık açısından koruyucu nitelikteyken (Dayığlu, 2008; Esen-Aktay, 2010; Magno, 2008; Mete, 2017; Terzi, 2008; Turan, 2014; Turgut, 2015; Turgut, 2018) yalnızlık, risk niteliği taşıyan bir faktördür (Altundağ, 2013; Güloğlu ve Karaırmak, 2010). Yine alanyazında sosyal dışlanmanın birey için benlik değeri, anlamlı varoluş ve kontrol ihtiyaçları açısından tehdit oluşturduğu (Kandemir, 2011; Aydın, Şahin, Güzel, Abayhan, Kaya ve Ceylan, 2013; Yılmaz-Anatca, 2010), sosyal dişlanmaya maruz kalan bireyin fiziksel ve sosyal uyarıcilarla ilgili algılarının bozulabilidiği (Zhong ve Leonardelli, 2008) ve dışlanmanın sonucunda bireyin yıkıcı davranışlara yönelebildiği (Twenge ve diğerleri 2002; Williams, 2007) bulguları yer almaktadır. Öte yandan sosyal kaygı yaşayan bireylerin ise diğer insanlarla ve ailesiyle yetersiz etkileşim ve sınırlı bir paylaşım içinde olduklarına (La Greca ve Lopez, 1998; Mehtalia ve Vankar, 2004), sosyal kaygı nedeniyle kendisine ve çevresine karşı olumsuz ve yıkıcı davranışlar sergileyebildiğine (Canoğulları, 2014; $\mathrm{Xu}$ ve diğerleri, 2012; Zorbaz, 2013) ilişkin bulgular yer almaktadır. Bu bulgular birlikte değerlendirildiğinde araştırma sonuçlarının alanyazın ile tutarlılık gösterdiği savunulabilir. Bu çerçevede sosyal kaygı yaşayan bireyin sosyal ortamlarda bulunma konusunda hissettiği gerginliğe bir de sosyal dışlanma durumunun eklenmesiyle bireyin daha da çaresiz ve yalnız hale geldiği, tüm bu süreçten psikolojik sağlamlığının da daha yüksek düzeyde olumsuz etkilendiği savunulabilir.

Araştırmada ergenlerde psikolojik sağlamlığın cinsiyet değişkenine göre anlamlı farklılıklar göstermediği sonucuna ulaşılmıştır. Alanyazındaki ilgili araştırmalara bakıldığında, Özcan (2005)'in lise öğrencilerinde, Ağırkan (2017)'nin üniversite öğrencilerinde, Sezgin (2012)'nin ise ilköğretim okulu öğretmenlerinde psikolojik sağlamlık düzeylerinin cinsiyet açısından anlamlı farklılık göstermediği sonucunu elde ettikleri görülmektedir. Benzer şekilde Akça (2012) ve Aydoğdu (2013) ve Doğruer (2019) da araştırmala- 
rında psikolojik sağlamlık düzeyinin cinsiyete göre anlamlı bir farklılık göstermediği sonucuna ulaşmışlardır. Bu açıdan araştırma bulgularının alanyazındaki bulgularla tutarlılık gösterdiği söylenebilir. Diğer taraftan alanyazında cinsiyet değişkeni açısından psikolojik sağlamlık düzeylerinin anlamlı farklılıklar gösterdiği araştırmalar da görülmektedir. Örneğin Kumpfer (1999) risk altındaki kız çocuklarının; Oktan (2008) üniversite sınavına hazırlanan kız ergenlerin, Onat (2010) ise liseye devam eden kız öğrencilerin psikolojik sağlamlık düzeylerinin erkeklerden daha yüksek olduğu sonucuna ulaşmışlardır. Buna karşılık Dayığlu (2008) üniversite giriş sınavına hazırlanan erkek öğrencilerin, Bulut (2016) erkek ergenlerin, Açıköz (2016) ve Atarbay (2017) ise üniversiteye devam eden erkek öğrencilerin psikolojik sağlamlık düzeylerinin kızlardan daha yüksek olduğu sonucuna ulaşmışlardır. Alanyazındaki araştırma bulguları birlikte düşünüldüğünde cinsiyet değişkeninin psikolojik sağlamlık açısından bazen koruyucu, bazen risk işlevi görebilirken çoğunlukla nötr bir etken olduğu söylenebilir. Bu durumun nedenlerinden biri toplumsal cinsiyet eşitliği yaklaşımlarının yaygınlaşması olabilir. Bu çerçevede ailelerin ve toplumun, fertlerine karşı cinsiyet ayrımı gözetmeksizin sergilediği yetiştirme tutumu ve destekleyici yaklaşımları sayesinde bireylerin de kendi cinsiyet kimlikleri açısından herhangi bir dezavantaj algısına kapılmadığı, böylece benzer psikolojik sağlamlık özellikleri gösterdikleri savunulabilir.

Araştırmada 7, 8, 9, 10 ve 11 . sinufa devam eden ergenlerin psikolojik sağlamlık düzeyinin 7. sınıftan 9. sinıfa doğru düşüş gösterip 9. sinıftan 11. sınıfa doğru tekrar yükseldiği fakat yalnızca 7. sınıf öğrencilerinin 9. sınıf öğrencilerinden anlamlı düzeyde yüksek psikolojik sağlamlığa sahip olduğu tespit edilmiştir. Alanyazında psikolojik sağlamlığın sınıf düzeyi açısından incelendiği bir araştırmaya ulaşılamamıştır. Yaş değişkeni açısından psikolojik sağlamlığı inceleyen bazı araştırmalarda ise; yetişkin örnekleminde farklı yaş gruplarına göre psikolojik sağlamlığın anlamlı farklılıklar göstermediği sonucuna ulaşılmıştır (Kahvecioğlu 2016; Küçüktatlıdil 2016). Yetişkinlerde yapılan başka bir araştırmada ise bireylerin yaşlarındaki artışın psikolojik sağlamlık düzeylerinde de artışı beraberinde getirdiği bildirilmiştir (Süzen, 2015). Bu araştırmadan elde edilen bulgu ergen bireyin eğitim kademelerindeki geçişi sürecinde deneyimlediği durumlarla açıklanabilir. Eğitim sistemimizde 7. sınıf, ortaokul kademesinin üçüncü yılına karşılık gelirken 9. sınıf, lise kademesinin ilk yılına karşılık gelmektedir. 7. 
sınıfa devam eden ergen 8 . sınıfa geçtiğinde onu daha belirsiz bir geleceğin beklediği söylenebilir. 8 . Sınıfın sonunda liseye geçiş için gireceği sınav geleceği ve kariyeri anlamında önemli dönüm noktalarından ilki sayılabilir. Bu sürecin sonunda 9. sınıfa geçerek liseye başlayan ergenin, eğitim kademeleri arasındaki bu geçişle okulu, arkadaşları, öğretmenleri ve sosyal çevresi belirgin bir değişikliğe uğramakta, bunun karşısında ergen alışageldiği tanıdık ve görece korunaklı ortamından çıkıp artık yeni, farklı akran ve yetişkinlerin olduğu, ayrıca akademik ve davranışsal anlamda (ders sayısı ve çeşidinin artması, sınıf geçme, devam ve disiplin yönetmeliklerine muhatap olması gibi) daha fazla sorumluluk yüklendiği bir eğitim kademesine geçmektedir. Bu çerçevede ergen bireyin 7. sınıftan 9. sınıfa geçiş sürecinde bir yandan her biri yeni uyum davranışını gerekli kılan bu çok yönlü değişimlerle başa çımak durumunda kalması, diğer yandan mevcut sosyal destek ve istikrar unsurlarının kesintiye uğraması nedeniyle psikolojik sağlamlık düzeyinin düşüş gösterdiği savunulabilir.

\section{Öneriler}

- Çalışma kapsamında elde edilen bulgulara göre ergen örnekleminde psikolojik sağlamlığın risk faktörleri arasında sosyal kaygı ve sosyal dışlanma değişkenlerine de yer verilebilir.

- Araştırma sonuçları doğrultusunda sosyal kaygı ve sosyal dışlanmayı azaltmaya yönelik önlemlerin, psikolojik sağlamlı̆̆ın artırılmasına da katkı sağlayacağı söylenebilir. Bu anlamda okul PDR planlarında sosyal kaygı ve sosyal dışlanmanın sağaltımına yönelik çalışmalara ve eğitim programlarına yer verilebilir.

- Sosyal destek bağlamında öğretmenlerin ve ailelerin farkındalığını artırmaya yönelik çalışmalar yapılabilir.

- Özellikle liseye yeni başlayan öğrencilerin psikolojik sağlamlık açısından kırılgan bir dönemde oldukları dikkate alınarak adaptasyonlarına katkı sağlayacak uyum ve başa çıkma becerilerini geliştirmeye yönelik eğitim programları hazırlanabilir.

- Araştırma farklı demografik özelliklere sahip çalışma gruplarında tekrarlanarak elde edilen sonuçların tutarlılılığı karşılatırılabilir.

- Alanyazında psikolojik sağlamlık ile ilgili deneysel çalışmaların az sayıda olduğu görülmektedir. Çeşitli gruplarda psikolojik sağlamlığı geliş- 
tirmeye yönelik programların oluşturulup etkililiği kanıtlananların yaygınlaştırılması, koruyucu ruh sağlığı hizmetlerine katkı sağlayabilir. Bu kavramla ilgili çalışma yapacak araştırmacıların bu ihtiyacı dikkate almaları yararlı olacaktır.

- Travma ve yoğun stres sonrasında yaşanan olumsuzlukların giderilmesinin daha zor ve maliyetli olduğu dikkate alınarak Sağlık Bakanlığı ve Milli Eğitim Bakanlığı işbirliği ile okul çağında psikolojik sağlamlı̆̆ın geliştirilmesine yönelik yaş gruplarına uygun beceri programları geliştirilebilir. 


\title{
EXTENDED ABSTRACT \\ Investigation of Resilience in Adolescents with Regards to Ostracism, Social Anxiety Gender and Grade Level
}

\author{
Yakup Işık - Eyüp Çelik \\ Sakarya University
}

Resilience is among the frequently researched variable in recent years. Defining as a process of adapting well in the face of significant stress sources, such as difficulty, trauma, tragedy, threat, family and relationship stressors, workplace and financial problems (APA, 2019; Newman, 2005), resilience concept's scope and dimensions are pointed out along with its importance for pereventive mental health by the researches (Carr, 2013; Eryllmaz, 2013; Gable and Haidth, 2005; Masten and Coatsworth, 1995; Öz and Yilmaz, 2009). Just as resilience has a remarkable role in the protection of mental health, determination of risk and protective factors also play an important role in the development of resilience (Arslan, 2015; Öz and Y1lmaz, 2009).

The destructive consequences of ostacism and social anxiety experiences that individuals may encounter in the socialization processes have been revealed through various studies (Baumeister, 1997; Canoğulları, 2014; La Greca and Lopez, 1998; Mehtalia and Vankar, 2004; Twenge et al., 2002; Waldrip, 2007; Zhong and Leonardelli, 2008; Zorbaz, 2013). In this regard, when unique conditions of adolescence during which peer relationships and social acceptance gain importance (Kulaksizoğlu, 2000; and Steinberg, 2007) and concepts of ostracism and social anxiety are evaluated jointly, relationships between the above mentioned phenomena need to be described in terms of age group. Analyzing the relevant literature, it has been observed that the resilience level of adolescents in different age groups who continue both secondary and high school education has not been investigated in terms of ostracism, social anxiety, gender, and grade level variables. For this reason, this research investigates adolescents' resilience level with regards to ostracism, social anxiety, gender, and grade level 
In this research, adolescents' resilience levels have been investigated in terms of social anxiety, ostracism, gender and grade levels within the scope of relational screening model.

The study group is comprised of 521 volunteer students attending the 7th, 8th, 9th, 10th and 11th grades of different public schools in Istanbul's Başakşehir (1 high school), Bayrampaşa (1 high school), Gaziosmanpaşa (1 high school) and Sultangazi (4 secondary schools, 2 high schools) districts in 2017-2018 academic year.

In this research, data on the adolescents' resilience levels have been obtained through Child and Youth Resilience Measure, data on the social exclusion level have been obtained through the Ostracism Experience Scale For Adolescents and data on the social anxiety level have been obtained through Social Anxiety Scale For Adolescents

As a result of the correlation analysis conducted to determine the relationships between the variables of the research, it has been discovered that in adolescents- along with statistically significant relationships, there is a moderate negative relationship between resilience and being ignored $(r=-$ .36), a low negative correlation between resilience and being excluded $(r=-$ $.20)$ and social anxiety $(r=-.28)$. Regression analysis has demonstrated that there is a statistically significant relationship between resilience variable and being ignored $(\beta=-.27, p<.001)$, being excluded $(\beta=-.10, p<.05)$ and social anxiety $(\beta=-.12, p<.05)$ variables. T-test results demonstrate that the level of resilience in terms of gender among adolescents was not significantly different $(p>.05)($ Male $=49.24, \mathrm{SS}=6,26$; Female $=49.81, \mathrm{SS}=6,37)$. As a result of a one-way ANOVA, it has been observed that the level of resilience in adolescents differs significantly in sense of grade level $\left(F_{(4,516)}=5.473, p<.001\right)$. Scheffe test results show that resilience level decreases from 7 th grade towards 9th grade and increases again from 9th grade to 11th grade. However, it was determined that only the difference between 7 th-grade adolescents and 9th-grade adolescents' resilience levels was statistically significant $(p<.001)$.

This research resulted in the fact that both sub-dimensions of ostracism (being ignored, being excluded) and social anxiety are significant predictors of resilience and the resilience level of the adolescents who experience social exclusion and social anxiety at the same time is affected more negatively. In the relevant literature, in sense of resilience, whereas personal resources like 
self-confidence, high self-esteem and positive attitude towards oneself are of individually protective qualities, the insufficiency of these resources are approached within the scope of individual risk factors (Eminağaoğlu, 2006; Masten, 1994; Romano and Hage, 2000). Likewise, while social support is a protective quality in sense of resilience (Dayığlu, 2008; Esen-Aktay, 2010; Magno, 2008; Mete, 2017; Terzi, 2008; Turan, 2014; Turgut, 2015; Turgut, 2018), loneliness is a risk factor (Altundağ, 2013; Güloğlu and Karaırmak, 2010). Moreover, relevant literature demonstrates that ostracism poses a threat to the individual in terms of fundamental needs for self-esteem, meaningful existence, and control (Kandemir, 2011; Aydın, Şahin, Güzel, Abayhan, Kaya, and Ceylan, 2013; Y1lmaz-Anatca, 2010), that perceptions of the individual -exposed to social exclusion- about physical and social stimuli may be impaired (Zhong and Leonardelli, 2008) and that individual could be inclined to destructive behaviors as a result of ostracism (Twenge et al., 2002; Williams, 2007). On the other hand, other findings reveal that individuals with social anxiety have insufficient interaction and limited sharing with other people and their families (La Greca and Lopez, 1998; Mehtalia and Vankar, 2004) and they may exhibit negative and destructive behaviors towards both themselves and their environment due to social anxiety (Canoğulları, 2014; Xu et al., 2012; Zorbaz, 2013). Evaluating these findings in the literature and this research's findings altogether, it could be argued that research findings are consistent with the literature. In this context, it could be maintained that the individual experiencing social anxiety becomes even more helpless and lonely due to ostracism and the tension that $\mathrm{s} / \mathrm{he}$ feels in social environments and thus, resilience is also adversely affected by this whole process.

In the research, it has been concluded that resilience in adolescents does not show significant differences in terms of gender. Looking at the relevant studies, it is observed that there has not been a significant difference in terms of gender in Özcan's (2005) high school students, Ağırkan's (2017) university students and Sezgin's (2012) primary school teachers. From this standpoint, it could be argued that research findings are consistent with other findings in the relevant literature. On the other hand, there are also other studies showing that resilience levels differ significantly in terms of gender variables (Kumpfer, 1999; Oktan, 2008; Onat, 2010). Taking these findings into consideration altogether, it could be argued that while gender 
variable sometimes can be a protective factor or sometimes a risk factor in terms of resilience, it is generally a neutral factor. One of the reasons for this situation could be the spreading of social gender equality approaches. In this regard, it could be maintained that thanks to the raising attitudes and supportive approaches displayed by families and society regardless of gender discrimination, individuals do not have any disadvantage perception in terms of their gender identity and thus, they display similar resilience characteristics.

In the research, it has been determined that the resilience level of 7th, 8th, 9th, 10th, and 11th-grade adolescents decreased from the 7th grade to the 9the grade and increased again from 9th grade to the 11the grade, however, only 7th-grade students had a significantly higher psychological resilience than 9th-grade students. In the literature, a study in which psychological resilience was examined in terms of grade-level could not be found. In some studies investigating the psychological resilience in terms of age variable, it has been concluded that psychological resilience does not show significant differences in accordance with different age groups in the adult sample (Kahvecioğlu 2016; Küçüktatlıdil 2016). In another study focused on adults, it has been reported that the increase in age also brings about an increase in the level of psychological resilience (Süzen, 2015). This finding could be explained by the situations experienced by the adolescent during his/her transition in educational levels. In our education system, 7th grade corresponds to the third year of secondary school and 9th grade corresponds to the first year of high school. The exam organized at the end of 8th grade as a transition to high school can be considered as the first turning point in terms of adolescent's future and career. At the end of this process, with this transition between educational levels, the school, friends, teachers and social environment of the adolescents who started high school -namely 9th gradechange significantly. In this case, adolescents move out of the familiar and relatively safeguarded environment they are accustomed to, and move to an educational level at which there are new, different peers and adults, and also more responsibility in academic and behavioral sense (increase in the number and variety of courses, passing class, being the object of attendance and discipline regulations, etc.) In this regard, it could be argued that as the adolescent passes from 7th grade towards 9th grade, his/her resilience level decreases since $s /$ he has to cope with these changes -each of which requires 
a new type of adaptive behavior- and existing social support and stability are interrupted.

\section{Kaynakça / References}

Açıkgöz, M. (2016). Çukurova Üniversitesi Tıp Fakültesi öğrencilerinin psikolojik sağlamlık ile mizah tarzları ve mutluluk düzeyi arasındaki ilişkinin incelenmesi Yüksek lisans tezi. YÖK Ulusal Tez Merkezi veri tabanından edinilmiştir. (Tez No. 443054)

Ağırkan, M. (2017).Üniversite öğrencilerinin değer yönelimleri ile psikolojik dayanıkllık düzeyleri arasındaki ilişki. Yüksek lisans tezi. YÖK Ulusal Tez Merkezi veri tabanından edinilmiştir. (Tez No. 466119)

Akça, Z. K. (2012). Genç yetişkinlikte algilanan anne-baba tutumlarımın, kendini toparlama gücü ve benlik saygısı arasındaki ilişki. Yüksek lisans tezi. YÖK Ulusal Tez Merkezi veri tabanından edinilmiştir. (Tez No. 314111)

Algünerhan. R. G. (2017). 12-14 yaşındaki ergenlerde algllanan ana baba tutumları benlik algısı ve psikolojik sağlamlı. Yüksek lisans tezi. YÖK Ulusal Tez Merkezi veri tabanından edinilmiştir. (Tez No. 458551)

Alkan, E. (2014). Farkl cinsel yönelime sahip bireylerin yaşam doyumu, stresle başa çıma stratejileri ve psikolojik dayanıkllık düzeylerinin karşılaştırılması. Yüksek lisans tezi. YÖK Ulusal Tez Merkezi veri tabanından edinilmiştir. (Tez No. 370315)

Altundağ, Y. (2013). Anne-babası boşanmış ergenlerin psikolojik dayanıkllık düzeylerinde yordayıcı değişkenler olarak yaşam doyumu ve yalnızllk. Yüksek lisans tezi. YÖK Ulusal Tez Merkezi veri tabanından edinilmiştir. (Tez No. 357721)

APA. (2019). The road to resilience. https://www.apa.org/helpcenter/roadresilience.aspx Adresinden 03 Şubat 2019 tarihinde erişildi.

Arslan, G. (2015). Çocuk ve genç psikolojik sağlamlık ölçeği'nin (ÇGPSÖ) psikometrik özellikleri: Geçerlilik ve güvenirlik çalışması. Ege Eğitim Dergisi, 16(1), 1-12. doi:10.12984/eed.23397

ASPB. (2014). Türkiye ergen profili araştırması. TEPA 2013 (T.C. Aile ve Sosyal Politikalar Bakanlığı, Aile ve Toplum Hizmetleri Genel Müdürlüğü). Ankara: Uzer Matbaacilı.

Atarbay, S. (2017). Farkh bölümlerde öğrenim gören üniversite öğrencilerinin sosyal kaygı düzeylerinin psikolojik dayanıklliklarına etkisi.Yüksek lisans tezi. YÖK Ulusal Tez Merkezi veri tabanından edinilmiştir. (Tez No. 451985) 
Aydın, A. ve Sütçü, S. T. (2007). Ergenler için sosyal kaygı ölçeği'nin (ESKÖ) geçerlik ve güvenirliğinin incelenmesi. Çocuk ve Gençlik Ruh Sağhlğ̆ Dergisi, 14(2), 79-89. Erişim adresi: http://apbs.mersin.edu.tr/files/arzu.aydin/Publications 007.pdf

Aydın, B. (2010). Üniversite öğrencilerinin duygusal zeka ve umut düzeyleri ile psikolojik sağlamlikları arasındaki ilişkinin incelenmesi. Yüksek lisans tezi. YÖK Ulusal Tez Merkezi veri tabanından edinilmiştir. (Tez No. 270930)

Aydın, O., Şahin, D., Güzel, H. Y., Abayhan, Y., Kaya, A. G. ve Ceylan, S. (2013). Ait olma ihtiyacının ve haberdar olmanın psikolojik dışlanmaya gösterilen tepkiler üzerindeki etkileri. Türk Psikoloji Dergisi, 28(72), 21-31. Erişim adresi: http://www.turkpsikolojiyazilari.com/PDF/TPD/72/02.pdf

Aydoğdu, T. (2013). Bağlanma stilleri, başa çıkma stratejileri ile psikolojik dayanıklllk arasındaki ilişkinin incelenmesi.Yüksek lisans tezi. YÖK Ulusal Tez Merkezi veri tabanından edinilmiştir. (Tez No. 333557)

Başak, E. B. (2012). Düşük gelirli ailelerden gelen üniversite öğrencilerinin öz duyarlık, sosyal bağlllık ve iyimserlik ile psikolojik dayanıkllık düzeyleri arasındaki ilişkiler. Doktora tezi.YÖK Ulusal Tez Merkezi veri tabanından edinilmiştir. (Tez No. 312585)

Batan, S. N. ve Ayten, A. (2015). Dini başa çıkma, psikolojik dayanıklılık ve yaşam doyumu ilişkisi üzerine bir araştırma. Din Bilimleri Akademik Araşttrma Dergisi, 15(3), 67-92. http://search.ebscohost.com/login.aspx?direct=trueanddb=edoandAN=1 $\underline{14472688 \text { andlang }=\text { trandsite }=\text { eds-liveandscope }=\text { siteandauthtype }=i p \text {,uid }}$ adresinden erişilmiştir.

Baumeister, R. F. (1997). Esteem threat, self-regulatory breakdown, and emotional distress as factors in self-defeating behavior. Review of General Psychology, 1(2), 145. doi:10.1037/1089-2680.1.2.145

Baumeister, R. F., Twenge, J. M. ve Nuss, C. K. (2002). Effects of social exclusion on cognitive processes: anticipated aloneness reduces intelligent thought. Journal of Personality and Social Psychology, 83(4), 817. doi:10.1037/0022-3514.83.4.817

Bulut, B. (2016). Ergenlerin anksiyete, sosyal destek ve psikolojik sağlamlik düzeyleri arasındaki ilişkilerin incelenmesi. Yüksek lisans tezi.YÖK Ulusal Tez Merkezi veri tabanından edinilmiştir. (Tez No. 433837)

Büyüköztürk, Ş. (2014). Sosyal bilimler için veri analizi el kitabı (Genişletilmiş 21. Baskl). Ankara: Pegem A Yayıncilık. 
Canoğulları, Ö. (2014). İnternet bağımlllk düzeyleri farklı ergenlerin cinsiyetlerine göre psikolojik ihtiyaçları, sosyal kaygları ve anne baba tutum algilarmnn incelenmesi. Yüksek lisans tezi. YÖK Ulusal Tez Merkezi veri tabanından edinilmiştir. (Tez No. 370878)

Carr, A. (2013). Positive psychology: The science of happiness and human strengths. New York: Routledge.

Chung, H. (2008). Resiliency and character strengths among college students. Doktora tezi.ProQuest Dissertations and Theses Global veri tabanından edinilmiştir. (Tez No. 89249786)

Çankaya, B. (2007). Lise I. ve II. sinı öğrencilerinin algılanan benlik saygısının bazı değişkenlere göre incelenmesi. Yüksek lisans tezi. YÖK Ulusal Tez Merkezi veri tabanından edinilmiştir. (Tez No. 207127)

Çokluk, O., Şekercioğlu, G. ve Büyüköztürk, Ş. (2012). Sosyal bilimler için çok değişkenli SPSS ve LISREL uygulamaları. Ankara: Pegem Yayıncilık.

Çuhadaroğlu, F. Ç., Canat, S., Kılıç, E. Şenol, S., Rugancı, N., Öncü, ... Avcı, A. (2004). Ergen ve ruhsal sorunları: Durum saptama çalıs̆ması. Ankara: Tübitak Matbaasi.

Dayığlu, B. (2008). Resilience in university entrance examination applicants: The role of learned resourcefulness, perceived social support, and gender.Yüksek lisans tezi. YÖK Ulusal Tez Merkezi veri tabanından edinilmiştir. (Tez No. 227695)

Dereboy, İ. F. (1993). Kimlik bocalaması, anlamak, tanımak, ele almak. Malatya: Özmert Ofset.

Doğruer, N. (2019). Çocukluk çağı trauma yaşantılarına sahip yetişkinlerde psikolojik dayanıklılı ve affetme.Yüksek lisans tezi, Sosyal Bilimler Enstitüsü. Erişim adresi: http://docs.neu.edu.tr/library/6716369680.pdf

Earvolino-Ramirez, M. (2007). Resilience: A concept analysis. Nursing Forum, 42(2), 73-82. doi:10.1111/j.1744-6198.2007.00070.x

Eminağaoğlu, N. (2006). Güç koşullarda yaşayan sokak çocuklarında dayanıklllk (sağlamlık). Doktora tezi.YÖK Ulusal Tez Merkezi veri tabanından edinilmiştir. (Tez No. 205267)

Erikson, E. H. (2014). İnsanın 8 evresi. (Çev. G. Akkaya).İstanbul: Okuyan Us Yayin.

Eriş, Y. ve İkiz, F. E. (2013). Ergenlerin benlik saygısı ve sosyal kaygı düzeyleri arasındaki ilişki ve kişisel değişkenlerin etkileri. Turkish Studies, 8(6), 179-193. doi:10.7827/TurkishStudies.4726 
Erol, N., Kılıç, C., Ulusoy, M., Keçeci, M. ve Şimsek, Z. (1998). Türkiye ruh să̆ğğ̆ profili raporu. Ankara: Eksen Tanitım Ltd Sti.

Eryılmaz, A. (2013). Pozitif psikolojinin psikolojik danışmanlık ve rehberlik alanında gelişimsel ve önleyici hizmetler bağlamında kullanılması. The Journal of Happiness and Well-Being, 3(1), 1-22. Erişim adresi: http://www.journalofhappiness.net/frontend/articles/pdf/v01i01/1.pdf

Esen-Aktay, T. (2010). Risk altındaki ortaöğretim 9. ve 10. sinıföğrencilerinin kendini toparlama güçlerinin incelenmesi. Yüksek lisans tezi.YÖK Ulusal Tez Merkezi veri tabanından edinilmiştir. (Tez No. 279580)

Eskin, M. (2000). Ergen ruh sağlığı sorunları ve intihar davranışıyla ilişkileri. Klinik Psikiyatri Dergisi, 3(4), 228-234. Erişim adresi: https://www.journalagent.com/kpd/pdfs/KPD 34228 234.pdf

Ferris, D. L., Brown, D. J., Berry, J. W. ve Lian, H. (2008). The development and validation of the Workplace Ostracism Scale. Journal of Applied Psychology, 93(6), 1348. Doi:10.1037/a0012743

Gable, S. L. ve Haidth, J. (2005). What (and why) is positive psychology? Review of General Psychology, 9(2), 103-110. doi:10.1037/1089-2680.9.2.103

Garmezy, N. (1987). Stress, competence, and development: Continuities in the study of schizophrenic adults, children vulnerable to psychopathology and the search for stress-resistant children. American Journal of Orthopsychiatry, 57(2), 159-174. doi:10.1111/j.1939-0025.1987.tb03526.x

George, D. ve Mallery, P. (2010). SPSS for windows step by step: A simple study guide and reference. India: Pearson Education.

Gilman, R., Carter-Sowell, A., DeWall, C. N., Adams, R. E. ve Carboni, I. (2013). Validation of the ostracism experience scale for adolescents. Psychological Assessment, 25(2), 319. doi:10.1037/a0030913

Güloğlu, B. ve Karaırmak, Ö. (2010). Üniversite öğrencilerinde yalnızlığın yordayıcısı olarak benlik saygısı ve psikolojik sağlamlık. Ege Üniversitesi Eğitim Fakültesi Dergisi,11(2), 73-88. Erişim adresi: https://pegem.net/dosyalar/dokuman/138236-20131221131630-4.pdf

Haase, J. E. (2004). The adolescent resilience model as a guide to interventions. Journal of Pediatric Oncology Nursing, 21(5), 289-299. doi:10.1177/1043454204267922

Işık E. ve Taner Y. I. (2006). Çocuk, ergen ve yetişkinlerde anksiyete bozuklukları. İstanbul: Asimetrik Paralel Yayınevi. 
Kahvecioğlu, K. (2016). Özel yetenekli çocuğu olan ebeveynlerin psikolojik să̆lamliklarının bazı değişkenler açısından incelenmesi. Yüksek lisans tezi. YÖK Ulusal Tez Merkezi veri tabanından edinilmiştir. (Tez No. 432645)

Kandemir, K. B. (2011). Psikolojik dişlanma, sosyal dışlanma ve sosyal reddedilmenin tehdit edilen ihtiyaçlar ve dışlanma tepkileri üzerindeki etkileri. Yüksek lisans tezi. YÖK Ulusal Tez Merkezi veri tabanından edinilmiştir. (Tez No. 308395)

Karaırmak, Ö. ve Çetinkaya, R. S. (2016). Benlik saygısının ve denetim odağının psikolojik sağlamlık üzerine etkisi: Duyguların aracı rolü. Türk Psikolojik Danışma ve Rehberlik Dergisi, 4(35). http://dergipark.gov.tr/download/article-file/200021 adresinden erişilmiştir.

Karasar, N. (2004). Bilimsel araştırma yöntemleri. Ankara: Nobel Yayıncılık.

Kidd, S. ve Shahar, G. (2008). Resilience in homeless Youth: The key role of selfesteem. American Journal of Orthopsychiatry, 8(2), 163-172. doi:10.1037/0002-9432.78.2.163

Kulaksızoğlu, A. (2000). Ergenlik psikolojisi. İstanbul: Remzi Kitabevi.

Kumpfer, K. L. (1999). Factors and processes contributing to resilience: the resilience framework. M. D. Glantz ve J. L. Johnson (Eds.), Resilience and development: Positive life adaptations içinde (s. 179-224). New York: Kluwer Academic/Plenum Publishers.

Küçüktatlıdil, S. (2016). Sigorta sektöründe çalışan kişilerin psikolojik dayanıklllık ve stresle başetme stratejilerinin bazı değişkenler açısından incelenmesi. Yüksek lisans tezi. YÖK Ulusal Tez Merkezi veri tabanından edinilmiştir. (Tez No. 438412)

La Greca, A. M. ve Lopez, N. (1998). Social anxiety among adolescents: Linkages with peer relations and friendships. Journal of Abnormal Child Psycho$\log y, 26(2), 83-94$. doi:10.1023/A:1022684520514

La Greca, A. M. ve Stone, W. L. (1993). Social anxiety scale for children-revised: Factor structure and concurrent validity. Journal of Clinical Child Psycho$\log y, 22(1), 17-27$. doi:10.1207/s15374424jccp2201_2

La Greca, A. M., Dandes, S. K., Wick, P., Shaw, K. ve Stone, W. L. (1988). Development of the Social Anxiety Scale for Children: Reliability and concurrent validity. Journal of Clinical Child Psychology, 17(1), 84-91. doi:10.1207/s15374424jccp1701_11 
Leary, M. R. (2005). Varieties of interpersonal rejection. K. D. Williams, J. P. Forgas ve W. Von Hippel, (Eds.), The social outcast: Ostracism, social exclusion, rejection, and bullying içinde (s. 35-51). New York: Psychology Press.

Leary, M. R. ve Kowalski, R. M., (1995). Social Anxiety. https://books.google.com.tr/books adresinden erişilmiştir.

Liebenberg, L., Ungar, M. ve LeBlanc, J. C. (2013). The CYRM-12: A brief measure of resilience. Canadian Journal of Public Health, 104(2), 131-135. doi:10.1007/BF03405676

Liebenberg, L., Ungar, M. ve Vijver, F. V. D. (2012). Validation of the child and youth resilience measure-28 (CYRM-28) among Canadian youth. Research on Social Work Practice, 22(2), 219-226. doi:10.1177/1049731511428619

Magno, C. (2008). The influence of self-mastery and communal-mastery on building a model of resiliency. Philippine Journal of Counseling Psychology, 2008 , 10(1),

$1-22$. https://papers.ssrn.com/sol3/Delivery.cfm/SSRN ID1429341 code12972 19.pdf?abstractid $=1429341$ andmirid $=1$ adresinden erişilmiştir.

Masten, A. (1994). Resilience in individual development: Successful adaptation despite risk and adversity. M. C. Wang ve E. W. Gordon (Eds.), Educational resilience in inner-city America: Challenges and prospects (3-25). https://books.google.com.tr/books adresinden erişilmiştir

Masten, A. S. ve Coatsworth, J. D. (1995). Competence, resilience, and psychopathology. D. Cicchetti ve D. Cohen (Eds.), Developmental psychopathology: Risk, disorder, and adaptation içinde (Cilt 2, s. 715-752). New York: Wiley.

Masten, A. S. ve Coatsworth, J. D. (1998). The development of competence in favorable and unfavorable environments: Lessons from research on successful children. American Psychologist, 53(2), 205. doi:10.1037/0003066X.53.2.205

Mehtalia, K. ve Vankar, G. K. (2004). Social anxiety in adolescents. Indian Journal of Psychiatry, 46(3), 221-227. http://citeseerx.ist.psu.edu/viewdoc/download?doi=10.1.1.350.9885andr ep=rep1andtype $=p d f$ adresinden erişilmiştir.

Mete, C. (2017). İzmir'de yaşayan Roman ergenlerin psikolojik sağlamliklarının algilanan sosyal destek, mizah kullanımı ve sosyal bağhllk düzeylerine göre incelenmesi. Yüksek lisans tezi. YÖK Ulusal Tez Merkezi veri tabanından edinilmiştir. (Tez No. 470470) 
Offer, D., Kaiz, M., Howard, K. I. ve Bennett, E. S. (1998). Emotional variables in adolescence, and their stability and contribution to the mental health of adult men: Implications for early intervention strategies. Journal of Youth and Adolescence, 27(6), 675-690. doi:10.1023/A:1022808314659

Oktan, V. (2008). Üniversite smavina hazırlanan ergenlerin psikolojik sağlamliklarımın çeşitli değişkenlere göre incelenmesi. Yüksek lisans tezi. YÖK Ulusal Tez Merkezi veri tabanından edinilmiştir. (Tez No. 231764)

Onat, G. (2010). Demokratik ve otoriter olarak algilanan ana-baba tutumlarmm lise birinci sını öğrencilerinin yılmazlı düzeyine etkilerinin araştırlması. Yüksek lisans tezi. YÖK Ulusal Tez Merkezi veri tabanından edinilmiştir. (Tez No. 278780)

Onur, B. (1993). Çocuk ve ergen gelişimi. Ankara: İmge Kitabevi.

Öz, F. ve Yılmaz, E. B. (2009). Ruh sağlığının korunmasında önemli bir kavram: Psikolojik sağlamlık. Hacettepe Üniversitesi Hemşirelik Fakültesi Dergisi, 16(3), 82-89. Erişim adresi: http://hacettepehemsirelikdergisi.org/pdf/pdf HHD 87.pdf

Özcan, B. (2005). Anne-babaları boşanmış ve anne-babalar birlikte olan lise öğrencilerinin yılmazlık özellikleri ve koruyucu faktörler açısından karşılaşttrılması. Yüksek lisans tezi. YÖK Ulusal Tez Merkezi veri tabanından edinilmiştir. (Tez No. 204978)

Öztürk, A. (2004). Sosyal kaygrya ilişkin kendini sunma modeli. Doktora tezi. YÖK Ulusal Tez Merkezi veri tabanından edinilmiştir. (Tez No. 145180)

Öztürk, M. O. (2002). Ruh sağhlğı ve bozuklukları. İstanbul: Nobel Tip Kitabevleri.

Romano, J. L. ve Hage S. M. (2000). Prevention and counseling psychology revitalizing commitments for the 21st century. The Counseling Psychologist, 28(6), 733-763. doi:10.1177/0011000000286001

Rutter, M. (1999). Resilience concepts and findings: Implications for family therapy. Journal of Family Therapy,21(2), 119-144. doi:10.1111/14676427.00108

Sarıkaya, A. (2015). 14 - 18 yaş arası ergenlerin benlik saygısı ve psikolojik dayanıklllk düzeyleri arasındaki ilişki.Yüksek lisans tezi. YÖK Ulusal Tez Merkezi veri tabanından edinilmiştir. (Tez No. 414642)

Sertelin-Mercan, Ç. S. (2016). Ergenler için sosyal dışlanma ölçeği: Türkçe geçerlik ve güvenirliği. Hayef: Journal of Education, 13(2), 175-186. http://dergipark.gov.tr/download/article-file/226054 adresinden erişilmiştir. 
Sezgin, F. (2012). İlköğretim okulu öğretmenlerinin psikolojik dayanıklılık düzeylerinin incelenmesi. Kastamonu Eğitim Dergisi, Mayıs, 20, 489-502. http://www.kefdergi.com/pdf/20 2/may\%C4\%B1s 2012.pdf\#page=129 adresinden erişilmiştir.

Souri, H. ve Hasanirad, T. (2011). Relationship between resilience, optimism and psychological well-being in students of medicine. Procedia-Social and Behavioral Sciences, 30, 1541-1544. doi:10.1016/j.sbspro.2011.10.299

Steinberg, L. (2007). Ergenlik. Ankara: İmge Kitabevi Yayınları.

Süzen, B. (2015). 1999 Marmara Depremini yaşamış bireylerin psikolojik dayanıklliklarının çeşitli değişkenler açısından incelenmesi. Yüksek lisans tezi). YÖK Ulusal Tez Merkezi veri tabanından edinilmiştir. (Tez No. 398312)

Tabachnick, B. G. ve Fidell, L. S. (2007). Using multivariate statistics. https://www.pearsonhighered.com/assets/preface/0/1/3/4/0134790545.p df Adresinden 03 Şubat 2019 tarihinde erişildi.

Terzi, Ş. (2008). Üniversite öğrencilerinde kendini toparlama gücü'nün içsel koruyucu faktörlerle ilişkisi. Hacettepe Üniversitesi Ĕ̆itim Fakültesi Dergisi, 35(35), 297-306.

http://www.efdergi.hacettepe.edu.tr/yonetim/icerik/makaleler/562published.pdf adresinden erişilmiştir.

Terzi, Ş. (2016). Üniversite öğrencilerinin psikolojik dayanıklılıkları ve algıladıkları sosyal destek arasındaki ilişki. Türk Psikolojik Danışma ve Rehberlik Dergisi, 3(29).

http://pdrdergisi.org/index.php/pdr/article/viewFile/239/169 adresinden erişilmiştir.

Toplu, A. (2017). Şiddete maruz kalan ergen öğrencilerin psikolojik sağlamliklar ile empati ve öz yeterlikleri arasındaki ilişkinin demografik değişkenlerle birlikte incelenmesi: Kahramanmaraş ili örneği. Yüksek lisans tezi. YÖK Ulusal Tez Merkezi veri tabanından edinilmiştir. (Tez No. 478828)

Toprak, H. (2014). Ergenlerde mutluluk ve yaşam doyumunun yordayıcısı olarak psikolojik sağlamllk ve psikolojik ihtiyaç doyumu: Yüksek lisans tezi. YÖK Ulusal Tez Merkezi veri tabanından edinilmiştir. (Tez No. 353103)

Turan, A. (2014). Ergenlerde çocukluk örselenme yaşantıları ve yllmazlı düzeyinin alg̨lanan sosyal destek açısından incelenmesi.Yüksek lisans tezi. YÖK Ulusal Tez Merkezi veri tabanından edinilmiştir. (Tez No. 372146)

Turgut, A. Ş. (2018). Türkiye'deki kurum bakımında büyümüş bireylerin psikolojik dayanıklllk (yılmazlik) düzeylerinin incelenmesi. Yüksek lisans tezi. YÖK Ulusal Tez Merkezi veri tabanından edinilmiştir. (Tez No. 504595) 
Turgut, Ö. (2015). Ergenlerin psikolojik să̆lamlık düzeylerinin, önemli yaşam olayları, algılanan sosyal destek ve okul bağhlı̆̆g açısından incelenmesi. Yüksek lisans tezi. YÖK Ulusal Tez Merkezi veri tabanından edinilmiştir. (Tez No. 395175)

Twenge, J. M., Catanese, K. R. ve Baumeister, R. F. (2002). Social exclusion causes self-defeating behavior. Journal of Personality and Social Psychology, 83(3), 606. doi:10.1037/0022-3514.83.3.606

Twenge, J. M., Catanese, K. R. ve Baumeister, R. F. (2003). Social exclusion and the deconstructed state: time perception, meaninglessness, lethargy, lack of emotion, and self-awareness. Journal of Personality and Social Psychology, 85(3), 409. doi:10.1037/0022-3514.85.3.409

Ülker Tümlü, G. ve Recepoğlu, E. (2013). Üniversite akademik personelinin psikolojik dayanıklılık ve yaşam doyumu arasındaki ilişki. Journal of Higher Education and Science/Yüksekögretim ve Bilim Dergisi, 3(3). http://higheredu-sci.beun.edu.tr/pdf/pdf HIG 1623.pdf adresinden erişilmiştir.

Waldrip, A. M. (2007). The power of ostracism: Can personality influence reactions to social exclusion? Doktora tezi. ProQuest Dissertations and Theses Global veri tabanından edinilmiştir. (Tez No. 275681981)

Werner, E. E. (1989). High-risk children in young adulthood: A longitudinal study from birth to 32 years. American Journal of Orthopsychiatry, 59(1), 72-81. doi:10.1111/j.1939-0025.1989.tb01636.x

Williams, K. D. (2001). Ostracism: The power of silence. https://books.google.com.tr/books adresinden erişilmiştir.

Williams, K. D. (2007). Ostracism. Annual Review of Psychology, 58, 425-452. doi:10.1146/annurev.psych.58.110405.085641

Williams, K. D. ve Zadro, L. (2005). Ostracism: The indiscriminate early detection system. K. D. Williams, J. P. Forgas ve W. Von Hippel (Eds.), The Social Outcast: Ostracism, Social Exclusion, Rejection and Bullying içinde (s.19-34). NewYork: Psychology Press.

Xu, Y., Schneier, F., Heimberg, R. G., Pirincisvalle, K., Liebowitz, M. R., Wang, S. ve Blanco, C. (2012). Gender differences in social anxiety disorder: Results from the national epidemiologic sample on alcohol and related conditions. Journal of Anxiety Disorders, 26, 12-19. doi:10.1016/j.janxdis.2011.08.006 
Yılmaz-Anatca, V. (2010). Sosyal dışlanmanın saldırgan davranışlar üzerindeki etkisi. Yüksek lisans tezi. YÖK Ulusal Tez Merkezi veri tabanından edinilmiştir. (Tez No. 265202)

Zhong, C. B. ve Leonardelli, G. J. (2008). Cold and lonely does social exclusion literally feel cold?. Psychological Science, 19(9), 838-842. doi:10.1111/j.1467-9280.2008.02165.x

Zorbaz, O. (2013). Lise öğrencilerinin problemli internet kullanımının sosyal kaygı ve akran ilişkileri açısından incelenmesi.Yüksek lisans tezi. YÖK Ulusal Tez Merkezi veri tabanından edinilmiştir. (Tez No. 339100)

\section{Kaynakça Bilgisi / Citation Information}

Işık, Y. ve Çelik, E. (2020). Ergenlerde psikolojik sağlamlığın sosyal dışlanma, sosyal kaygı, cinsiyet ve sınıf düzeyi açısından incelenmesi OPUS-Uluslararası Toplum Araştırmaları Dergisi, 16(27), 174-209. DOI: 10.26466/opus.642037 